Int. J. Plant Sci. 169(3):409-431. 2008.

(c) 2008 by The University of Chicago. All rights reserved.

1058-5893/2008/16903-0008\$15.00 DOI: $10.1086 / 526468$

\title{
EVOLUTION AND PHYLOGENETIC IMPORTANCE OF ENDOCARP AND SEED CHARACTERS IN VIBURNUM (ADOXACEAE)
}

\author{
Bart Jacobs, ${ }^{1, *}$ Michael J. Donoghue, † Ferry Bouman, $\ddagger$ Suzy Huysmans,* and Erik Smets*` \\ *Laboratory of Plant Systematics, Katholieke Universiteit Leuven, Kasteelpark Arenberg 31, P.O. Box 2437, BE-3001 Leuven, Belgium; \\ tDepartment of Ecology and Evolutionary Biology, Yale University, P.O. Box 208106, New Haven, Connecticut 06520-8105, U.S.A.; \\ ¥Hugo de Vries Laboratory, Universiteit van Amsterdam, Kruislaan 318, NL-1098 SM Amsterdam, The Netherlands; and \\ §Nationaal Herbarium Nederland, Leiden University Branch, P.O. Box 9514, NL-2300 RA Leiden, The Netherlands
}

Recent phylogenetic analyses based on molecular markers have resulted in a solid phylogeny of Viburnum with 12 well-defined clades. This has allowed us to focus on character evolution, endocarp and seed characters in particular. Members of Viburnum bear drupes that differ considerably between clades. Characters such as pyrene shape and grooving, number of fibrous layers, seed coat anatomy, and seed rumination are phylogenetically highly valuable. Our results largely agree with the results based on molecular data and provide several additional insights. The position of V. clemensae as sister to the rest of Viburnum is supported by several characters. The early diversification of $V$. clemensae might explain its highly derived features. Furthermore, our results give an indication of the possible paraphyly of the Megalotinus clade, confirm the paraphyly of Hara's section Solenotinus, and support the split of Hara's section Odontotinus into four well-defined clades. Endocarp and seed characters are mainly useful at the level of individual clades. Several characters, however, are useful at higher taxonomic levels. The presence of small, amorphous crystals in the endosperm, for example, is most likely to be apomorphic for Viburnum within the order Dipsacales.

Keywords: Viburnum, Adoxaceae, endocarp, seed, evolution, phylogeny.

\section{Introduction}

The genus Viburnum L. has long been placed in the Caprifoliaceae (Hutchinson 1967, 1973; Thorne 1976; Takhtajan 1980; Cronquist 1981) or in a family of its own, the Viburnaceae (Dahlgren 1980, 1989). Nowadays, Viburnum is placed in the family Adoxaceae (Dipsacales sensu APG II 2003), together with Sambucus, Adoxa, Sinadoxa, and Tetradoxa (Eriksson and Donoghue 1997; Donoghue et al. 2001; APG II 2003). With ca. 158 species of shrubs and small trees, Viburnum constitutes the majority of the family, which contains ca. 200 species. The genus is distributed around the Northern Hemisphere and has significant extensions into the mountains of Southeast Asia and South America. Eastern Asia and Latin America are marked centers of species diversity (Hara 1983; Donoghue et al. 2004; Winkworth and Donoghue 2004, 2005).

Viburnum, like most Dipsacales, is characterized by opposite (rarely whorled), entire leaves and terminal inflorescences (Donoghue 1983a, 1983b). Viburnum forms a well-defined "natural" group and can therefore be easily distinguished from its closest relative, Sambucus (Donoghue 1983a, 1983b). The latter genus has compound leaves, drupes with several pyrenes, extrorse anthers, and simple vessel perforations, whereas Viburnum has simple, rarely ternate, leaves, drupes with a single pyrene, introrse anthers, and scalariform vessel perforations (Donoghue 1983a, 1983b). Although the general morphology of fruits and flowers is relatively uniform within Viburnum,

${ }^{1}$ E-mail: bart.jacobs@bio.kuleuven.be.

Manuscript received April 2007; revised manuscript received August 2007. various polymorphic characters have allowed botanists to set up a sectional classification (Oersted 1861; Rehder 1940; Donoghue 1983a, 1983b; Hara 1983). Endocarp shape, structure of winter buds, and presence of extrafloral nectaries are examples of traits that are most useful in sectional delimitation (Cross 1938; Wilkinson 1948; Donoghue 1983a, 1983b). The structure and development of the ovary, as well as the anatomy and morphology of the fruit, probably distinguish Viburnum the most from related genera (Wilkinson 1948; Fukuoka 1972). Species delimitation is often obscure, as Kern (1951) clearly demonstrated for some Malaysian species of $\mathrm{Vi}$ burnum.

Recently, three molecular studies were carried out to clarify the infrageneric relationships within Viburnum using both chloroplast (trnK and $p s b A-t r n H$ ) and nuclear (nrITS, WAXY1, and WAXY2) markers (Donoghue et al. 2004; Winkworth and Donoghue 2004, 2005). These studies have resulted in a well-resolved phylogeny, although some clades still suffer from a lack of resolution. The results of these studies largely confirm the monophyly of the sections defined by Hara (1983). However, a number of differences should be taken into account (fig. 1).

First of all, five sections appeared to be paraphyletic. Section Odontotinus fell apart into an Asian clade (Old World [OW] Odontotinus) and a North American clade (New World [NW] Odontotinus). The North American clade also included the paraphyletic section Oreinotinus. Sections Lentago, Solenotinus, and Viburnum turned out to be paraphyletic as well. However, in each case, a single species was placed outside of a monophyletic core group. 


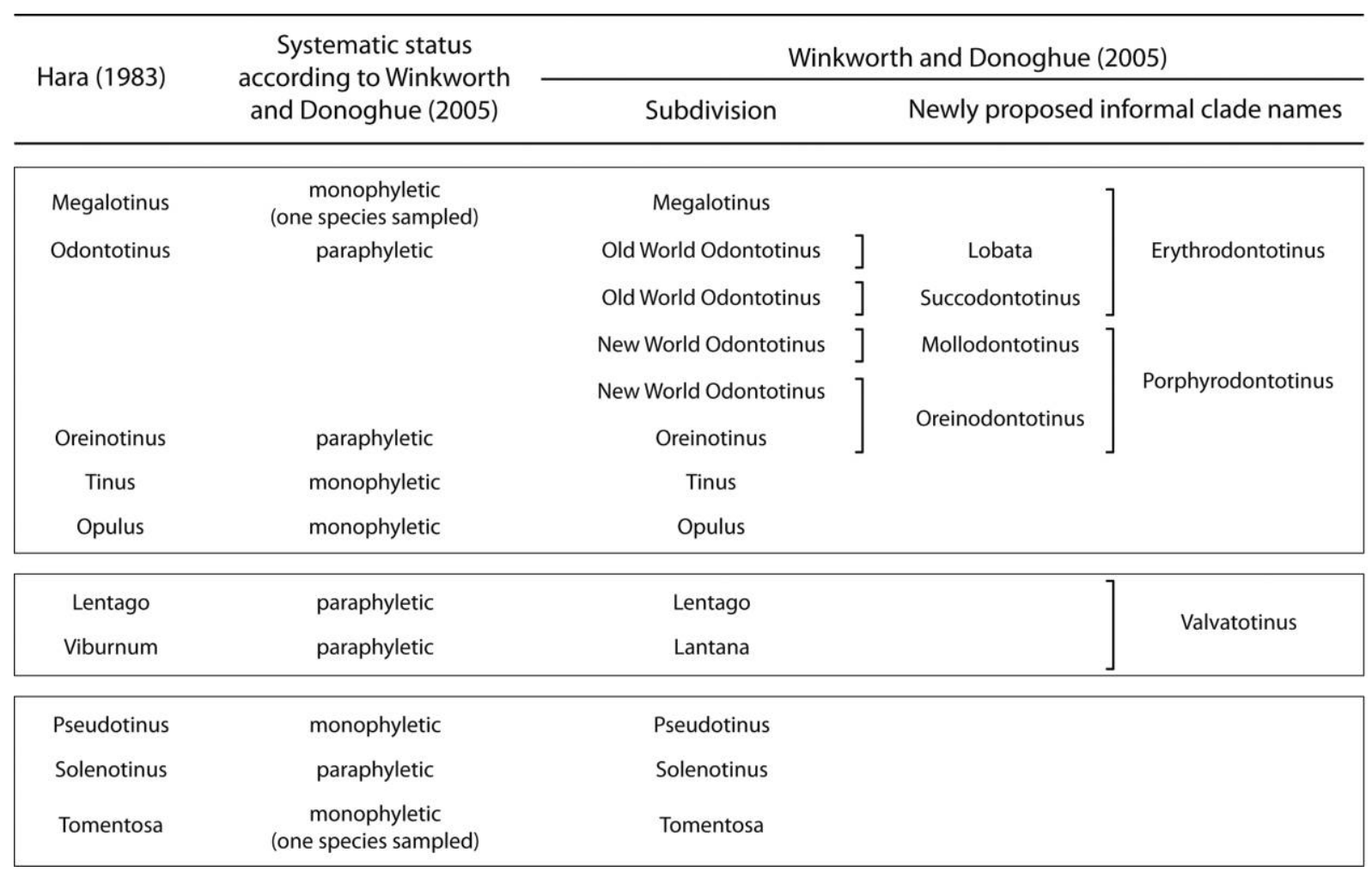

Fig. 1 Overview of Viburnum classification.

Second, three suprasectional clades were acknowledged. (1) The largest clade contains the traditional sections Megalotinus, Odontotinus, Opulus, Oreinotinus, and Tinus. (2) A second clade groups sections Lentago and Viburnum together with V. nudum (section Lentago). (3) Sections Solenotinus and Tomentosa form a clade, together with V. urceolatum (section Lantana). V. clemensae appeared to be sister to the rest of the genus, although this relationship was only weakly supported.

Finally, Winkworth and Donoghue (2005) proposed a new classification based on both the work of Hara (1983) and molecular data (fig. 1). In order to facilitate future discussion, informal clade names were proposed for several species groups. Viburnum acerifolium and V. kansuense were grouped into Lobata, which forms a monophyletic group with the remaining Asian species of the traditional section Odontotinus. The latter clade was renamed Succodontotinus. Oreinodontotinus accommodates the traditional section Oreinotinus and $V$. dentatum (NW Odontotinus). NW Odontotinus without $V$. dentatum was renamed Mollodontotinus. Finally, to avoid confusion between the genus Viburnum and section Viburnum, the latter was renamed section Lantana. The classification proposed by Winkworth and Donoghue (2005) is taken up in this study.

Although the diversity of fruits and seeds of the Dipsacales is considerable for an order of its size, the diversity is not well documented. Several authors (e.g., Corner 1976; Takhtajan 2000) have provided a brief description of the order or a selection of families. However, few studies have dealt thoroughly with the morphology and anatomy of the fruits and seeds of the different clades. Hara (1983) offered a revision of the Caprifoliaceae of Japan as well as the Adoxaceae and refers to allied species in other parts of the world. Donoghue et al. (2003) studied the evolution of several morphological characters within the order Dipsacales, fruit type being one of them. A series of papers was published by Mayer and collaborators (Mayer 1995; Mayer and Svoma 1998; Mayer and Ehrendorfer 1999, 2000), with special focus on fruit and epicalyx morphology and anatomy, as well as its evolution within the family Dipsacaceae. A paper about the Caprifoliaceae of Poland treats Viburnum and its relatives (Maciejewska 1998).

The inquiries of Hara (1983), Mayer and collaborators (Mayer 1995; Mayer and Svoma 1998; Mayer and Ehrendorfer 1999, 2000), and Donoghue et al. (2003) clearly illustrate the phylogenetic and systematic value of fruit characters. Mayer and Ehrendorfer (1999), for example, point out the usability of fruit characters to support phylogenetic relationships as well as systematic delimitation of genera of the $\mathrm{Sca}$ biosa group and of the genus Pseudoscabiosa. Hara (1983) discusses the phylogenetic relationships of the Caprifoliaceae and Adoxaceae on the basis of morphological data. Fruit characters, as well as seed characters, turn out to be of great use, not least within the genus Viburnum. Donoghue et al. (2003) study the phylogenetic value of several fruit characters (e.g., epicalyx morphology). The results of our study illustrate the versatility of fruit characters, i.e., the usability of fruit characters on different taxonomic levels.

The morphology and anatomy of the drupes and seeds of Viburnum are subject to significant variation (Donoghue 1983b; Hara 1983). Several studies (e.g., Hara 1983; Donoghue et al. 
2004) have shown the phylogenetic value of fruit and seed characters. A thorough study of the morphology and anatomy of the fruits and seeds of the genus Viburnum, as well as the phylogenetic value of fruit and seed characters, has not been done at this writing. The aim of this study is twofold: (1) the documentation of the diverse morphology and anatomy of the seeds and pyrenes of Viburnum and (2) the identification and plotting of phylogenetically valuable characters onto the most recent phylogeny (Winkworth and Donoghue 2005) in order to discuss character evolution.

\section{Material and Methods}

Seeds and pyrenes of 31 species (37 specimens) of Viburnum (see appendix) were investigated using light microscopy (LM) and scanning electron microscopy (SEM). Plant material was obtained through collaboration with seed banks and herbaria or was collected in the field and in botanic gardens (see appendix for details).

For anatomical investigations, after fixation with glutaraldehyde $(2 \%)$ buffered with sodium cacodylate buffer $(0.05 \mathrm{M})$, the material was dehydrated in an ethanol series. Seeds and pyrenes were embedded in a resin based on hydroxyethylmethacrylate (Technovit 7100, Kulzer Histo-Technik, Wehrheim, Germany). A graded series of resin and acetone was made to improve infiltration of the resin. The resin blocks were cut into $5-\mu \mathrm{m}$ sections with a rotation microtome (HM360, Microm, Walldorf, Germany) equipped with a carbide knife. Longitudinal and cross sections were made from all specimens. The sections were stained with toluidine blue, observed with a Leitz Dialux 20 microscope (Leitz, Wetzlar, Germany), and photographed with a DP50-CU digital camera (Olympus, Hamburg, Germany).

For morphological investigations, the same fixation and dehydration protocols were applied, with the following adjustments. During dehydration, the material was submerged in an ultrasonic water bath to remove dust particles and excess fatty acids. After dehydration, pyrenes were put in hydrogen peroxide $(35 \%)$ for $3-4 \mathrm{~h}\left(60^{\circ} \mathrm{C}\right)$ in order to remove remnants of the mesocarp. Thereafter, the pyrenes were cleaned with a toothbrush and treated ultrasonically once more. Both seeds and pyrenes were dried in an oven $\left(30^{\circ} \mathrm{C}\right)$ before being mounted on stubs, coated with gold (Spi-Supplies, Walldorf, Germany), and observed with a JSM-6360 scanning electron microscope at $10 \mathrm{kV}$ (JEOL, Tokyo).

Crystal composition was determined by means of energydispersive $\mathrm{x}$-ray spectroscopy. The tissues of interest were mounted on stubs, sputtered with gold (Spi-Supplies), and observed with an XL30-FEG scanning electron microscope $(20 \mathrm{kV})$ equipped with an EDAX-DX-4i energy-dispersive $\mathrm{X}$-ray detector for microchemical analysis (Philips, Eindhoven, Netherlands).

A Leica MZ6 stereomicroscope (Leica Microsystems, Heerbrugg, Switzerland) was used to measure seeds and pyrenes. Seed coat thickness and endocarp thickness were measured using a Leitz Dialux 20 microscope equipped with a DP50CU digital camera (Olympus) and AnalySIS 3.2 (Soft Imaging System, Münster, Germany).

Character evolution was studied by means of maximum parsimony with MacClade 4.0 (Maddison and Maddison
2002) and a modified version of the molecular phylogeny of Winkworth and Donoghue (2005; fig. 5B). The phylogeny was altered in such a way that only species sampled in our study and the study of Winkworth and Donoghue (2005) were included in the parsimony optimization analyses. This resulted in a sampling of 17 species that covers all species groups recognized by Winkworth and Donoghue (2005), with the exception of Oreinodontotinus and Mollodontotinus. After construction of the modified phylogeny in MacClade 4.0, phylogenetically informative characters were plotted onto the phylogeny by creating a matrix with all the included species and their respective character states for a selection of key characters.

In "Discussion," we also refer to additional species for which we have data on some of the characters used here. This additional information-on endocarp shape and seed rumination, in particular-was obtained in earlier studies of fruit morphology (M. J. Donoghue, unpublished data) and is documented as detailed camera lucida drawings of fruit, pyrene, and seed cross sections of 108 Viburnum species, representing all of the traditional sections of Hara (1983) and the clades of Winkworth and Donoghue (2005). These additional observations are especially useful in establishing the precise distribution of the characters of interest and allow us, in some cases, to confidently assess in detail any correspondence to prior taxonomic groups and hypothesized clades.

\section{Results}

\section{Pyrene Morphology and Anatomy}

Shape and size. While interspecific variation is considerable, intraspecific differences are small (table 1). All species studied have bilaterally symmetrical pyrenes with dorsal and ventral surfaces. Some species seem to have radially symmetrical pyrenes, but the presence of dorsal and ventral grooves (see below) and the ventral pyrene scar make a distinction between the dorsal and ventral surface possible. Four types of variation are considered: (1) overall shape, (2) shape in dorsal view, (3) shape in cross section, and (4) size.

Three types are considered with respect to overall pyrene shape: (1) discoid (fig. 2E), (2) curved discoid (discoid pyrenes with the lateral margins ventrally curved inward; fig. 2C), (3) globoid (fig. 2F), and (4) cylindrical. Lantana, Lentago, and Opulus are examples of clades that are typically characterized by discoid pyrenes. Curved discoid pyrenes, on the other hand, mark the Solenotinus clade. A number of species belonging to the Tinus and Oreinodontotinus clades have globoid pyrenes. Species with cylindrical pyrenes can be found in the Tinus clade as well.

Six character states can be distinguished regarding pyrene shape in dorsal view: (1) elliptical (fig. 2A), (2) ovate, or egg shaped (fig. 2B), (3) clavate (fig. 2C), (4) spindle shaped, or fusiform (fig. 2D), (5) cordate, or heart shaped (fig. 2E), and (6) lacryform, or drop shaped (fig. $2 F$ ). The distinction between the different character states is often vague, and intraspecific variation can occur.

Pyrene shape in cross section and grooving are considered as a single character divided into five well-defined character states: (1) compressed, undulate, where the undulations mostly 
Table 1

Pyrene Characteristics of the Studied Species of Viburnum

\begin{tabular}{|c|c|c|c|c|c|c|c|c|c|c|}
\hline Taxon & $\begin{array}{c}\text { Winkworth and } \\
\text { Donoghue }(2005) \\
\text { species group }\end{array}$ & $\begin{array}{l}\text { Length } \\
(\mathrm{mm})\end{array}$ & $\begin{array}{l}\text { Width } \\
(\mathrm{mm})\end{array}$ & $\begin{array}{l}\text { Thickness } \\
(\mathrm{mm})\end{array}$ & $\begin{array}{l}\mathrm{L} / \mathrm{W} \\
\text { ratio }\end{array}$ & $\begin{array}{l}\text { Endocarp } \\
\text { shape and } \\
\text { grooving }^{\mathrm{a}}\end{array}$ & $\begin{array}{l}\text { Maximum } \\
\text { no. fibrous } \\
\text { layers }^{b}\end{array}$ & $\begin{array}{l}\text { Endocarp } \\
\text { thickness } \\
(\mu \mathrm{m})\end{array}$ & $\begin{array}{l}\text { No. cell } \\
\text { layers }\end{array}$ & Crystals $^{c}$ \\
\hline V. acerifolium L. & Lobata & $6.6 \pm .5$ & $5.9 \pm .6$ & $2.6 \pm .3$ & 1.1 & 1 & 1 & $171 \pm 50$ & $4-5$ & 1 \\
\hline V. betulifolium Batalin & Succodontotinus & $5.7 \pm .3$ & $4.5 \pm .2$ & $3.0 \pm .1$ & 1.3 & 1 & 1 & $179 \pm 24$ & $4-6$ & 1 \\
\hline V. bitchiuense Makino & Lantana & $8.4 \pm .3$ & $5.9 \pm .6$ & $2.8 \pm .2$ & 1.4 & 1 & 2 & $181 \pm 44$ & $4-7$ & 2 \\
\hline V. carlesii Hemsley & Lantana & $8.5 \pm .4$ & $5.8 \pm .4$ & $2.3 \pm .2$ & 1.5 & 1 & 2 & $161 \pm 22$ & $4-6$ & 2 \\
\hline V. clemensae Kern & $\ldots$ & $9.2 \pm 1.0$ & $6.1 \pm .3$ & $5.8 \pm .2$ & 1.5 & 4 & 2 & $131 \pm 30$ & $7-8$ & 0 \\
\hline V. cotinifolium D. Don. & Lantana & $7.4 \pm .5$ & $5.2 \pm .2$ & $2.2 \pm .2$ & 1.4 & 1 & 2 & $167 \pm 14$ & $4-6$ & 0 \\
\hline V. cylindricum & & $5.6 \pm .2$ & $3.9 \pm .2$ & $2.0 \pm .2$ & 1.4 & & & $69 \pm 27$ & $2-5$ & \\
\hline Ham. ex D. Don. & Megalotinus & & & & & 1 & 2 & & & 2 \\
\hline V. dasyanthum Rehder & Succodontotinus & $7.6 \pm .3$ & $3.5 \pm .2$ & $2.2 \pm .2$ & 2.2 & 1 & 1 & $95 \pm 28$ & $3-6$ & 2 \\
\hline V. davidii Franch. & Tinus & $5.6 \pm .5$ & $3.2 \pm .3$ & $2.8 \pm .1$ & 1.8 & 5 & 2 & $113 \pm 22$ & $3-5$ & 0 \\
\hline V. dilatatum Thunb. & Succodontotinus & $6.3 \pm .8$ & $5.1 \pm .7$ & $2.5 \pm .2$ & 1.2 & 1 & 1 & $122 \pm 30$ & $3-5$ & 1 \\
\hline V. foetidum Wall. & Succodontotinus & $4.7 \pm .3$ & $4.1 \pm .2$ & $2.2 \pm .2$ & 1.1 & 1 & 1 & $111 \pm 19$ & $3-5$ & 1 \\
\hline V. fordiae Hance & Succodontotinus & $5.6 \pm .5$ & $4.7 \pm .3$ & $3.1 \pm .4$ & 1.2 & 1 & 1 & $194 \pm 43$ & $3-7$ & 2 \\
\hline V. glabratum H. B. \& K. & Oreinodontotinus & $4.4 \pm .5$ & $3.9 \pm .5$ & $3.0 \pm .4$ & 1.1 & 5 & 1 & $126 \pm 56$ & $3-5$ & 0 \\
\hline V. hupehense Rehder & Succodontotinus & $7.2 \pm .3$ & $5.0 \pm .3$ & $2.7 \pm .4$ & 1.4 & 1 & 1 & $148 \pm 29$ & $4-6$ & 1 \\
\hline V. ichangense Rehder & Succodontotinus & $5.8 \pm .4$ & $4.7 \pm .2$ & $2.8 \pm .2$ & 1.3 & 1 & 1 & $198 \pm 77$ & $4-6$ & 2 \\
\hline V. lantana $\mathrm{L}$. & Lantana & $6.8 \pm .2$ & $6.1 \pm .2$ & $2.6 \pm .2$ & 1.1 & 1 & 2 & $193 \pm 27$ & $5-7$ & 1 \\
\hline V. lantanoides Michaux & Pseudotinus & $7.0 \pm .3$ & $6.1 \pm .3$ & $3.4 \pm .1$ & 1.2 & 3 & 2 & $171 \pm 47$ & $4-8$ & 0 \\
\hline V. lentago L. & Lentago & $9.7 \pm .7$ & $8.9 \pm .4$ & $2.9 \pm .1$ & 1.1 & 2 & 1 & $159 \pm 64$ & $4-6$ & 0 \\
\hline V. lobophyllum Graebn. & Succodontotinus & $6.0 \pm .5$ & $4.1 \pm .3$ & $2.3 \pm .2$ & 1.5 & 1 & 1 & $116 \pm 31$ & $4-5$ & 1 \\
\hline V. luzonicum Rolfe & Succodontotinus & $3.7 \pm .1$ & $3.3 \pm .2$ & $1.8 \pm .1$ & 1.1 & 1 & 1 & $173 \pm 52$ & $3-7$ & 0 \\
\hline V. odoratissimum & & $6.5 \pm .6$ & $4.1 \pm .3$ & $1.4 \pm .2$ & 1.6 & & & $96 \pm 37$ & $2-6$ & \\
\hline Ker Gawler & Solenotinus & & & & & 4 & 2 & & & 1 \\
\hline V. opulus L. & Opulus & $7.6 \pm .1$ & $7.0 \pm .5$ & $2.1 \pm .1$ & 1.1 & 2 & 1 & $110 \pm 29$ & $4-5$ & 1 \\
\hline $\begin{array}{l}\text { V. plicatum var. } \\
\text { tomentosum (Thunb.) }\end{array}$ & & $5.1 \pm .4$ & $3.7 \pm .1$ & $2.1 \pm .1$ & 1.4 & & & $135 \pm 41$ & $5-7$ & \\
\hline Miquel & Tomentosa & & & & & 1 & 1 & & & 1 \\
\hline V. prunifolium L. & Lentago & $5.7 \pm .5$ & $3.9 \pm .2$ & $2.0 \pm .2$ & 1.5 & 2 & 1 & $123 \pm 35$ & $3-5$ & 0 \\
\hline V. rhytidophyllum Hemsley & Lantana & $8.0 \pm .4$ & $4.5 \pm .3$ & $2.1 \pm .5$ & 1.8 & 1 & 2 & $168 \pm 29$ & $3-6$ & 1 \\
\hline V. sambucinum & & $8.8 \pm .2$ & $6.3 \pm .2$ & $2.8 \pm .1$ & 1.4 & & & $160 \pm 36$ & $3-6$ & \\
\hline Reinw. ex Blume & Megalotinus & & & & & 1 & 1 & & & 1 \\
\hline V. sargentii Koehne & Opulus & $7.3 \pm .6$ & $6.7 \pm .4$ & $2.6 \pm .5$ & 1.1 & 2 & 1 & $94 \pm 26$ & $3-6$ & 1 \\
\hline V. setigerum Hance & Succodontotinus & $9.6 \pm .4$ & $5.5 \pm .5$ & $2.1 \pm .2$ & 1.8 & 1 & 1 & $186 \pm 37$ & $4-6$ & 1 \\
\hline V. sieboldii Miquel & Solenotinus & $7.6 \pm .1$ & $4.9 \pm .1$ & $3.1 \pm .2$ & 1.5 & 4 & 2 & $190 \pm 75$ & $3-7$ & 0 \\
\hline V. tinus L. & Tinus & $6.3 \pm .3$ & $5.2 \pm .3$ & $5.1 \pm .2$ & 1.2 & 5 & 1 & $137 \pm 24$ & $4-6$ & 3 \\
\hline V. veitchii Wright & Lantana & $7.6 \pm .4$ & $5.9 \pm .3$ & $2.3 \pm .0$ & 1.3 & 1 & 2 & $177 \pm 22$ & $4-7$ & 1 \\
\hline
\end{tabular}

a $1=$ compressed, undulate; $2=$ compressed, nonundulate; $3=$ curved, undulate; $4=$ curved, nonundulate; $5=$ circular to elliptical, notched.

b $1=$ one layer of fibrous cells; $2=$ two or more layers of fibrous cells.

c $0=$ no crystals; $1=$ scattered idioblasts containing a single crystal; $2=$ groups of crystal-containing cells; $3=$ a more or less continuous layer of crystal-containing cells.

reflect the presence of dorsal and ventral grooves (each groove, in turn, corresponds to the position of an associated vascular bundle running through the mesocarp from the base of the ovary toward the apex; fig. 2G); (2) compressed, nonundulate, which lacks evident grooves (fig. $2 \mathrm{H}$ ); (3) curved, undulate, or horseshoe shaped, with grooves on the dorsal and ventral surfaces (fig. 2I); (4) curved, nonundulate, horseshoe shaped but lacking prominent grooves (fig. 2J); and (5) circular to elliptical, notched, where a major, possibly composite, groove runs along the center of the ventral surface (fig. $2 K$ ). The motivation for the grouping of pyrene shape in cross section and grooving into a single character is given in "Discussion." Dorsal and ventral grooves are present in all species except those belonging to Opulus (fig. $2 E, 2 N$ ) and the majority of the species of Lentago. The presence of the grooves affects both pyrene and seed shape. The pattern of grooves generates a distinct sculpture on both the dorsal and ventral surfaces (fig. $2 L, 2 M$ ).

Pyrene size varies significantly within Viburnum (table 1). Within species, however, variation in size is limited. The largest pyrenes were observed in $V$. lentago $(9.7 \mathrm{~mm} \times 8.9 \mathrm{~mm} \times 2.9$ $\mathrm{mm})$ and the smallest in V. luzonicum $(3.7 \mathrm{~mm} \times 3.3 \mathrm{~mm} \times 1.8$ $\mathrm{mm})$.

Endocarp structure. General endocarp anatomy is uniform within Viburnum (fig. 3A-3F). Endocarp thickness, the number of cell layers, and the degree of cell sclerification, however, are subject to substantial interspecific variation (table 1).

Two layers constitute the endocarp, an outer layer of mostly isodiametric sclereids (one to five cell layers, rarely none) and an inner layer of elongated, spindle-shaped fibers 

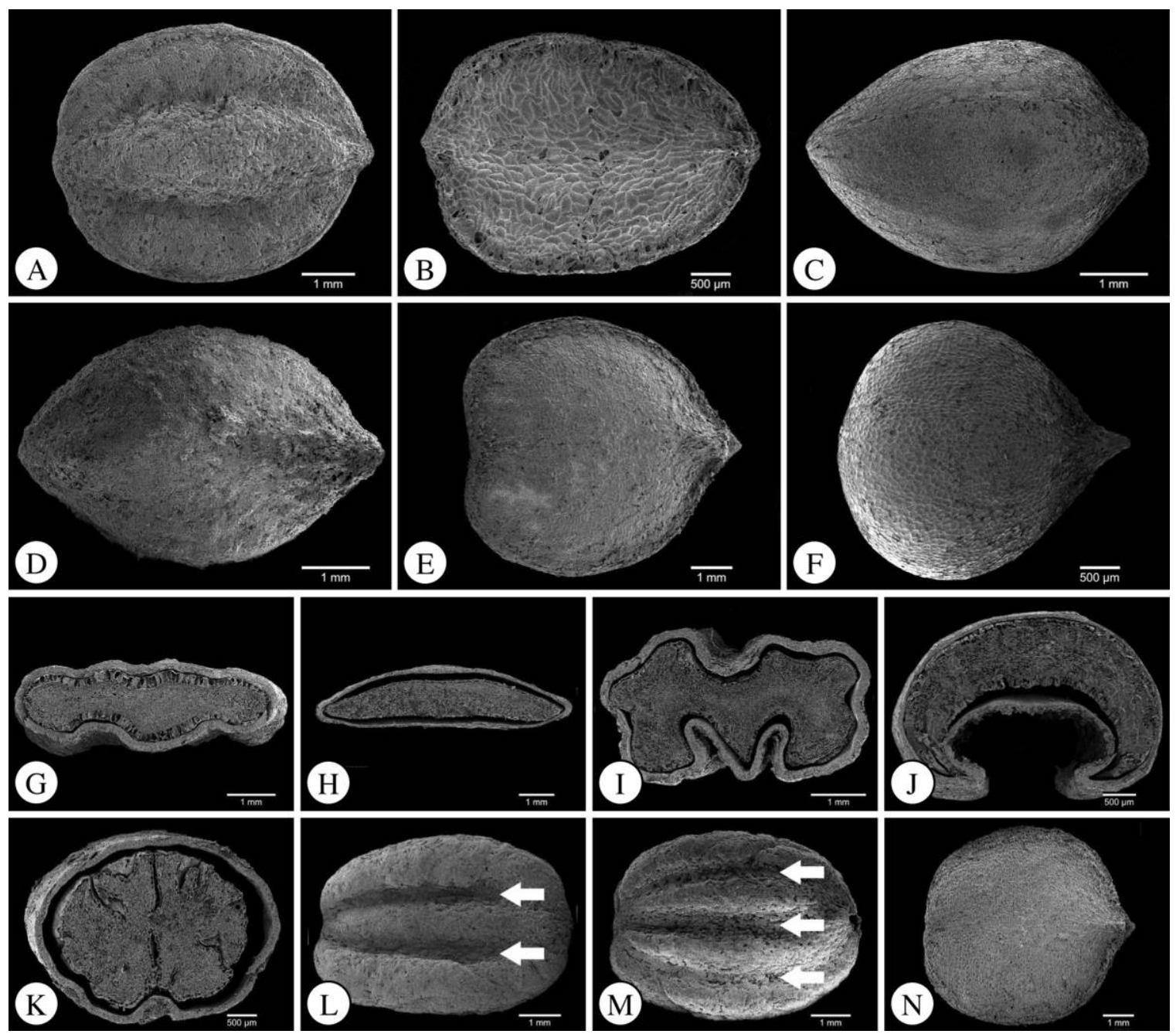

Fig. 2 Pyrene morphology in Viburnum (SEM). A-F, Pyrene shape in dorsal view. A, V. hupehense, elliptical outline; B, V. cylindricum, ovate outline; C, V. odoratissimum, clavate outline; D, V. prunifolium, spindle-shaped, or fusiform, outline; E, V. opulus, cordate, or heart-shaped, outline, no dorsal grooves; F, V. glabratum, lacryform outline. G-K, Pyrene shape in cross section, grooving. G, V. lantana, compressed, undulate; $H, V$. opulus, compressed, nonundulate; $I, V$. lantanoides, curved, undulate; J, V. odoratissimum, curved, nonundulate; K, V. tinus, circular to elliptical. $L-N$, Presence/absence of dorsal and ventral grooves. L, V. cotinifolium, two dorsal grooves (arrows); M, V. cotinifolium, three ventral grooves (arrows); N, V. opulus, no ventral grooves.

(one to five cell layers; fig. $3 A-3 F$ ). Often, a clear distinction between sclereids and fibers can be made. In a number of species, however, the difference between the two cell types is less obvious, and a gradual transition between sclereids and fibers can be observed. Mostly, the size of the sclereids is relatively constant within a layer but varies between layers, i.e., increasing in size toward the exterior (fig. $3 B$ ). The longitudinal axis of the fibers is oriented perpendicular to the longitudinal axis of the pyrene, which results in a characteristic pattern (fig. 3J; see "Inner surface" below).

Within Viburnum, the number of cell layers varies from two to eight. Viburnum cylindricum, for example, is characterized by a thin, flexible endocarp (two to five cell layers), while pyrenes of $V$. lantanoides have a thick, rigid endocarp (four to eight cell layers). The number of endocarp cell layers of a single specimen is quite variable as well (fig. 3D). Pyrene margins, for example, are predominantly thicker than the rest of the endocarp because of an increased number of cell layers. In particular, the number of fibrous layers increases at the margins of the pyrene.

Cell lumen size differs significantly at the infrageneric level (fig. 3A-3F). Within Viburnum, the cell lumen size of the fibers is subject to some variation, although not very much. The cell lumina of the sclereids, however, range from a minute cell lumen to a cell wall that is only slightly thickened (fig. $3 A-3 C)$. The size of the cell lumen of the sclereids differs from layer to layer and is mostly species specific.

Outer surface. The sculpted pyrene surface is to a large extent defined by mesocarp anatomy; i.e., adjacent mesocarp cells shape the outer layer of sclereids of the endocarp (fig. 

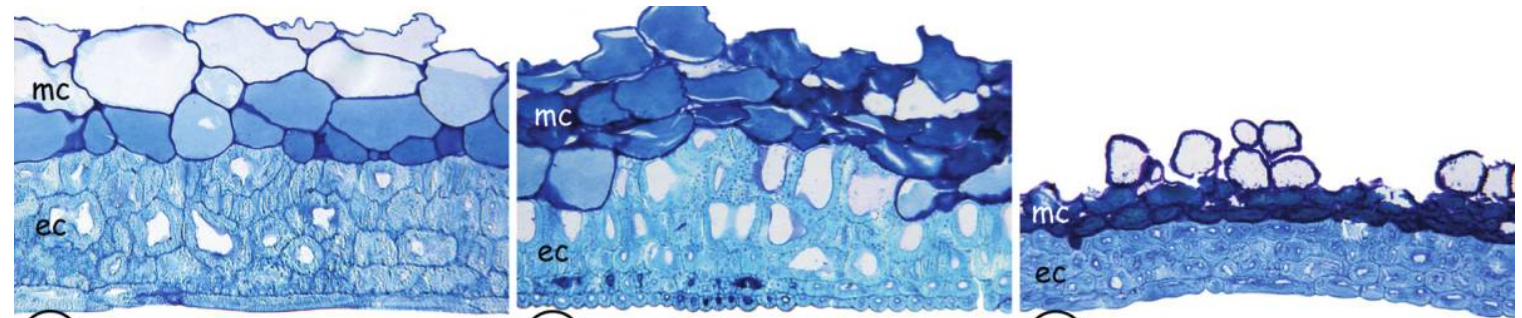

(A)

$-2-1$ B

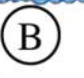

(C)

100 m
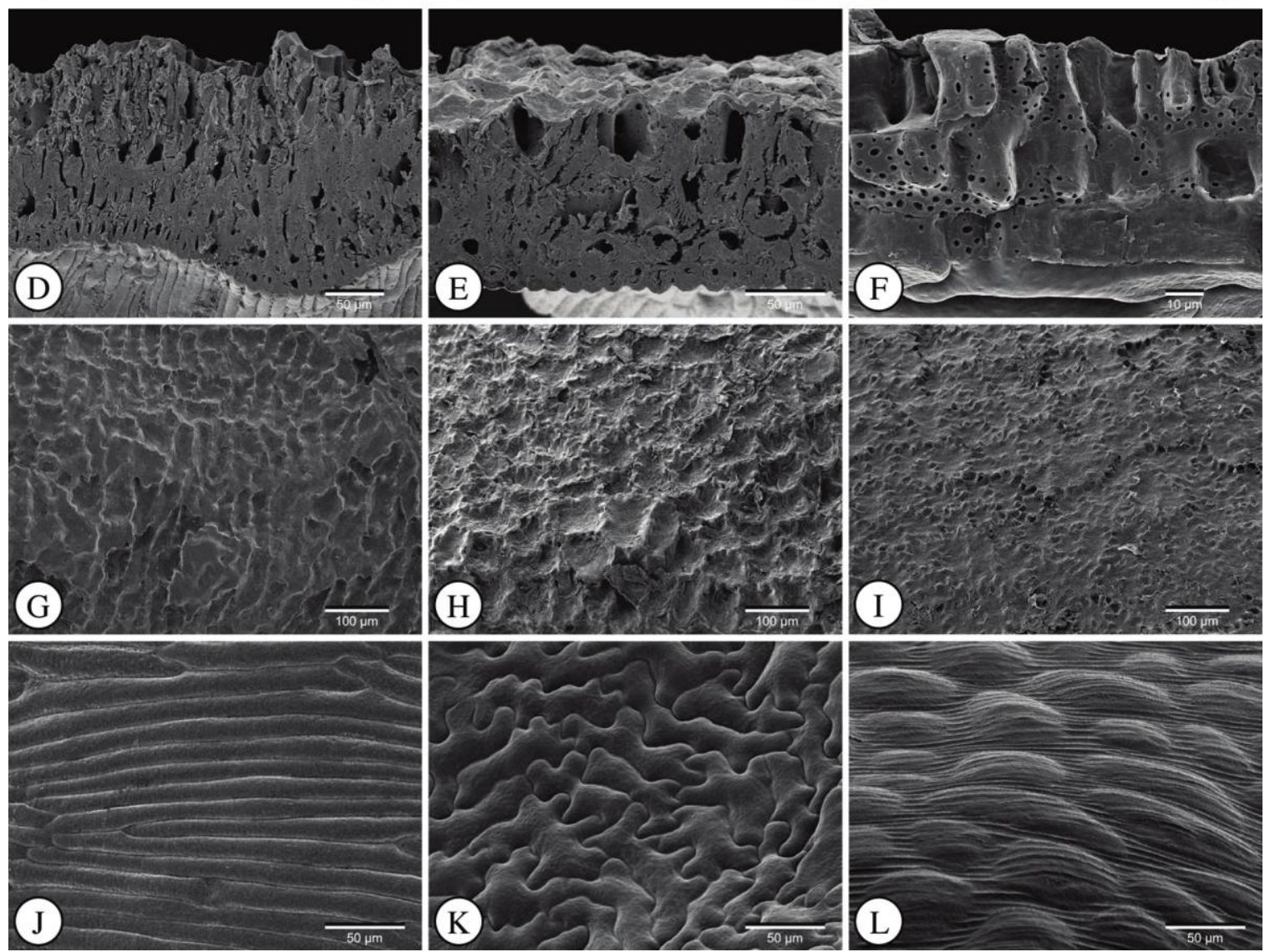

Fig. 3 Endocarp structure and surface in Viburnum. A-C, LM; D-L, SEM. A-F, Endocarp structure. A, V. betulifolium, cross section, sclerified endocarp $(e c)$ and parenchymatous mesocarp $(m c) ; B, V$. lentago, longitudinal section, sclereids with large cell lumina; $C$, V. davidii, longitudinal section, thin endocarp with small sclereids; $D, V$. betulifolium, longitudinal section, varying endocarp thickness; E, V. lentago, longitudinal section; F, V. davidii, cross section. G-I, Outer pyrene surface. G, V. rhytidophyllum, elongated imprints with modest undulating outline; H, V. glabratum, elliptical imprints with modest undulating outline; $I, V$. odoratissimum, elliptical imprints with strong undulating outline. $J-L$, Inner pyrene surface. $J$, V. lentago, spindle-shaped fibers; $K, V$. davidii, elongated fibers with undulating anticlinal walls; $L$, $V$. odoratissimum, spindle-shaped fibers with tetragonal imprints of seed coat.

$3 A-3 C)$. The imprints of the mesocarp cells create a distinct sculpture (fig. 3G-3I). The pattern is primarily defined by the size and shape of the bordering mesocarp cells, and the latter differs significantly within Viburnum (fig. 3A-3C). The fruits of the Tinus and Solenotinus clades, for example, have a thin layer of mesocarp composed of small cells. This results in a relatively smooth pyrene surface, compared with the pyrenes of the Lantana clade, for example. The pyrene surface of members of the Lantana clade is rough and uneven because of the presence of large, adjacent mesocarp cells.
In most cases, a prominent difference in cell size, shape, and sclerification is visible between endocarp and mesocarp (fig. $3 A-3 C)$. Viburnum cylindricum illustrates this well in having large, slightly elongated mesocarp cells that are adjacent to much smaller, isodiametric endocarp cells. In a number of species, however, a gradual transition between endocarp and mesocarp cells can be observed, resulting in cells that are difficult to identify (i.e., mesocarp or endocarp).

Inner surface. One to five layers of fibers constitute the inner endocarp layer and generate a characteristic pattern (fig. 
3J). As mentioned above ("Endocarp structure"), the fibers are mostly elongated, spindle-shaped cells and are circular to elliptical in cross section (fig. $3 A, 3 D, 3 J$ ). A number of species, however, deviate from this pattern. Viburnum davidii is marked by the presence of elongated cells with undulating cell walls, creating a jigsaw puzzle appearance (fig. $3 K$ ). The inner endocarp surfaces of $V$. odoratissimum (fig. $3 L$ ), $V$. glabratum, and $V$. cinnamomifolium show a sculpture that separates them from most other species examined. In spite of the fact that the fibers are elongated and spindle shaped, the sculpture deviates substantially from the typical pattern seen in Viburnum (fig. 3J). A pattern of tetragonal (V. glabratum) or circular to elliptical (V. odoratissimum; fig. $3 L$ ) imprints can be observed. In the case of $V$. glabratum, a striate pattern further characterizes the inner endocarp surface. The deviating pattern is caused by the adjacent seed coat in the same way that the mesocarp shapes the outer endocarp surface.

\section{Seed Morphology and Anatomy}

Shape and size. In general, seed shape and size correspond well with pyrene shape and size, with the exception of $V$. clemensae (tables 1, 2; fig. 4A, 4B, 4E, 4F, 4I, 4J). The seed fits the available space provided by the endocarp (tables 1,2). Endocarp shape affects seed shape and sets limits to seed size. However, in most species, the parenchymatous seed coat is well developed instead of being transformed into a thin seed coat composed of compressed cell layers (fig. 4M4O). As expected, the largest seeds were observed in V. lentago $(9.2 \mathrm{~mm} \times 8.4 \mathrm{~mm} \times 2.0 \mathrm{~mm})$ and the smallest in $V$. luzonicum $(3.5 \mathrm{~mm} \times 3.0 \mathrm{~mm} \times 1.4 \mathrm{~mm})$. The shape and size of seeds are not considered in detail here since they are mostly well reflected by those of the pyrene.

Seed coat anatomy and morphology. The seeds of Viburnum are marked by a parenchymatous seed coat (fig. 4C, 4D, $4 G, 4 H, 4 K-4 O)$. The number of cell layers and cell morphology are subject to variation.

In general, at maturity, the seed coat consists of a welldeveloped exotesta characterized by a single prominent layer of parenchymatous cells that are large in comparison with the cells of the adjacent endosperm (fig. 4M-4O). A number of species, as well as the entire Pseudotinus clade, are characterized by local proliferations of this prominent cell layer, resulting in invaginations, i.e., rumination (fig. 5D, see "Rumination" below).

In a few cases, one or two additional cell layers lie between the prominent cell layer and the endosperm. The cells of these layers are considerably smaller, mostly slightly flattened, and less obvious (fig. 4N). Cell shape and size of the prominent cell layer differ greatly within the genus. Seed coat cell shape can be divided into two character states: (1) seed coat cells that are higher than they are wide (i.e., columnar, or palisadelike; fig. 4M) and (2) seed coat cells that are as high as they are wide (i.e., cuboid; fig. $4 \mathrm{~N}$ ) or wider than they are high (i.e., rectangular, with the longer axis parallel to the seed surface; fig. 4O). Cell size is significantly smaller near and at the seed margins. The shape and size of the seed coat cells of the raphe and antiraphe are markedly different (fig. 5E-5H). The cells are smaller and elongated, with their axes parallel to the longitudinal axis of the vascular bundle (fig. $5 E-5 H$ ). The differ- ence in cell shape is not surprising, since the cells surrounding the vascular bundle are, in fact, part of the funicle that fuses with the seed coat during ovule development.

Because of the parenchymatous nature of the seed coat cells, the seed coat is fragile and easily damaged. A number of species produce seeds with seed coat cells that contain a viscous substance. In a few cases, the space between seed and endocarp is filled with this substance. In a dry environment, the viscous substance hardens and forms a layer on top of the seed coat.

The primary sculpture, as defined by Barthlott (1981), is quite variable and tends to be more species specific than clade specific. The seed coat cells of species belonging to the Lantana clade, however, are markedly larger than those found in other clades. This is in agreement with anatomical observations of the seed coat. The outline of the seed coat cells differs considerably within Viburnum as well (fig. 4C, 4D, 4G, 4H, $4 K, 4 L)$, although, once again, this seems to be species specific.

Only a few of the sampled species are characterized by a secondary sculpture. Viburnum dilatatum, V. betulifolium, and $V$. davidii (fig. $4 K, 4 L$ ) show a slight form of striation on the outer tangential wall.

Endosperm. A few well-defined features characterize the endosperm of Viburnum. (1) In general, the cell walls are relatively thick (fig. 4Q, 4R). This results in a hard tissue, especially when compared with the soft seed coat surrounding the endosperm. In a few species, however, the endosperm cell walls are less thickened (fig. 4P). (2) Cells of the endosperm contain one to several small, amorphous calcium oxalate crystals (fig. 5J). (3) In most of the species examined, one to several peripheral cell layers have a different morphology and anatomy when compared with the rest of the endosperm cells (fig. 4M-4O). The cells are usually smaller and have a different cell content. Crystals, for example, are absent in these cells.

Rumination. A seed is ruminate if the surface of any part of the seed is irregular or uneven (Werker 1997). Seed rumination is restricted to the seed coat and the endosperm; raphe and antiraphe are not taken into consideration.

Both ruminate and nonruminate seeds are found. Three well-defined types of rumination can be distinguished. (1) Type 1 rumination is a result of the shape and structure of the surrounding endocarp (fig. 5B-5D). (2) Type 2 and 3 ruminations are due to uneven growth of specific tissues of the seed, i.e., seed coat and endosperm, and develop independently of the adjacent endocarp (fig. 5B-5D). Types 2 and 3 differ in two aspects. The seed coat of type 2 ruminate seeds is composed of a single cell layer (cf. nonruminate seeds; fig. $5 B, 5 C)$. Type 3 ruminate seeds, however, have a seed coat that is locally proliferated, i.e., multilayered (fig. 5D). This difference in seed coat anatomy is correlated with the type of invaginations observed in both types. Type 2 rumination is characterized by narrow but more invasive invaginations. The invaginations can be seen when observing the seed surface (fig. 4I, 4J; fig. 5B, 5C). The invaginations found in type 3 ruminate seeds are the result of the locally proliferated seed coat and are broader and more shallow. Finally, two subtypes of type 2 rumination are considered. The number of invaginations is higher for type $2 \mathrm{~A}$, which is in part responsible for a lower amount of endosperm (fig. $5 B$ ). Furthermore, the invaginations of type $2 \mathrm{~A}$ rumination are oriented perpendicular 
Table 2

Seed Characteristics of the Studied Species of Viburnum

\begin{tabular}{|c|c|c|c|c|c|c|c|c|c|c|c|}
\hline \multirow[b]{2}{*}{ Taxon } & \multirow{2}{*}{$\begin{array}{l}\text { Winkworth and } \\
\text { Donoghue (2005) } \\
\text { species group }\end{array}$} & \multirow[b]{2}{*}{$\begin{array}{l}\text { Length } \\
(\mathrm{mm})\end{array}$} & \multirow[b]{2}{*}{$\begin{array}{l}\text { Width } \\
(\mathrm{mm})\end{array}$} & \multirow[b]{2}{*}{$\begin{array}{l}\text { Thickness } \\
(\mathrm{mm})\end{array}$} & \multirow[b]{2}{*}{$\begin{array}{l}\mathrm{L} / \mathrm{W} \\
\text { ratio }\end{array}$} & \multicolumn{3}{|c|}{ Seed coat } & \multicolumn{3}{|c|}{ Rumination } \\
\hline & & & & & & $\begin{array}{l}\text { Thickness } \\
(\mu \mathrm{m})\end{array}$ & $\begin{array}{l}\text { No. cell } \\
\text { layers }\end{array}$ & $\begin{array}{l}\text { Cell } \\
\text { shape }^{\text {a }}\end{array}$ & $\begin{array}{l}\text { Type } \\
1^{\mathrm{b}}\end{array}$ & $\begin{array}{l}\text { Type } \\
2^{\mathrm{c}}\end{array}$ & $\begin{array}{c}\text { Type } \\
3^{\mathrm{b}}\end{array}$ \\
\hline V. acerifolium L. & Lobata & $6.4 \pm .4$ & $6.7 \pm .7$ & $1.8 \pm .1$ & 1.0 & $106 \pm 31$ & $2-3$ & 2 & 1 & 0 & 0 \\
\hline V. betulifolium Batalin & Succodontotinus & $5.4 \pm .3$ & $4.1 \pm .2$ & $2.4 \pm .2$ & 1.3 & $99 \pm 30$ & $1-3$ & 2 & 1 & 0 & 0 \\
\hline V. bitchiuense Makino & Lantana & $7.8 \pm .6$ & $5.4 \pm .3$ & $2.5 \pm .1$ & 1.4 & $160 \pm 69$ & 1 & 1 & 1 & 0 & 0 \\
\hline V. carlesii Hemsley & Lantana & $7.3 \pm .4$ & $5.2 \pm .2$ & $1.9 \pm .1$ & 1.4 & $112 \pm 45$ & 1 & 1 & 0 & 0 & 0 \\
\hline V. clemensae Kern & None & $5.6 \pm .5$ & $4.8 \pm .2$ & $4.0 \pm .1$ & 1.2 & $56 \pm 16$ & 1 & 1 & 1 & 1 & 0 \\
\hline V. cotinifolium D. Don. & Lantana & $6.7 \pm .4$ & $4.8 \pm .2$ & $1.8 \pm .1$ & 1.4 & $144 \pm 44$ & $1-2$ & 1 & 1 & 0 & 0 \\
\hline V. cylindricum & & $4.5 \pm .2$ & $3.4 \pm .1$ & $1.7 \pm .1$ & 1.3 & $190 \pm 55$ & 1 & & & & \\
\hline Ham. ex D. Don. & Megalotinus & & & & & & & 1 & 1 & 0 & 0 \\
\hline V. dasyanthum Rehder & Succodontotinus & $6.5 \pm .3$ & $3.0 \pm .2$ & $1.6 \pm .3$ & 2.2 & $74 \pm 11$ & $1-3$ & 2 & 1 & 0 & 0 \\
\hline V. davidii Franch. & Tinus & $5.5 \pm .1$ & $2.8 \pm .1$ & $2.5 \pm .1$ & 2.0 & $99 \pm 52$ & 1 & 2 & 1 & 2 & 0 \\
\hline V. dilatatum Thunb. & Succodontotinus & $5.9 \pm .5$ & $4.6 \pm .3$ & $1.9 \pm .2$ & 1.3 & $60 \pm 20$ & $1-2$ & 2 & 0 & 0 & 0 \\
\hline V. foetidum Wall. & Succodontotinus & $4.5 \pm .3$ & $3.5 \pm .3$ & $2.0 \pm .2$ & 1.3 & $92 \pm 11$ & 1 & 2 & 1 & 0 & 0 \\
\hline V. fordiae Hance & Succodontotinus & $4.6 \pm .2$ & $3.9 \pm .1$ & $2.7 \pm .3$ & 1.2 & $65 \pm 14$ & 1 & 2 & 1 & 0 & 0 \\
\hline V. glabratum H. B. \& K. & Oreinodontotinus & $4.4 \pm .2$ & $4.2 \pm .3$ & $2.9 \pm .3$ & 1.0 & $37 \pm 11$ & 1 & 2 & 1 & 0 & 0 \\
\hline V. hupehense Rehder & Succodontotinus & $6.3 \pm .5$ & $4.4 \pm .2$ & $1.8 \pm .2$ & 1.4 & $88 \pm 16$ & $1-2$ & 2 & 1 & 0 & 0 \\
\hline V. ichangense Rehder & Succodontotinus & $4.8 \pm .4$ & $4.1 \pm .2$ & $1.9 \pm .4$ & 1.2 & $62 \pm 18$ & $1-2$ & 2 & 1 & 0 & 0 \\
\hline V. lantana $\mathrm{L}$. & Lantana & $6.3 \pm .2$ & $5.7 \pm .2$ & $2.0 \pm .2$ & 1.1 & $189 \pm 69$ & $1-2$ & 1 & 1 & 0 & 0 \\
\hline V. lantanoides Michaux & Pseudotinus & $6.4 \pm .4$ & $5.3 \pm .4$ & $2.8 \pm .2$ & 1.2 & $160 \pm 79$ & $1-2$ & 1 & 1 & 0 & 1 \\
\hline V. lentago L. & Lentago & $9.2 \pm .6$ & $8.4 \pm .4$ & $2.0 \pm .3$ & 1.1 & $213 \pm 74$ & $1-2$ & 1 & 0 & 0 & 0 \\
\hline V. lobophyllum Graebn. & Succodontotinus & $5.2 \pm .6$ & $3.5 \pm .1$ & $1.7 \pm .3$ & 1.5 & $25 \pm 10$ & 1 & 2 & 1 & 0 & 0 \\
\hline V. luzonicum Rolfe & Succodontotinus & $3.5 \pm .2$ & $3.0 \pm .1$ & $1.4 \pm .1$ & 1.2 & $47 \pm 14$ & $1-2$ & 2 & 1 & 0 & 0 \\
\hline V. odoratissimum & & $5.7 \pm .4$ & $3.6 \pm .1$ & $1.3 \pm .1$ & 1.6 & $92 \pm 39$ & 1 & & & & \\
\hline Ker Gawler & Solenotinus & & & & & & & 1 & 1 & 0 & 1 \\
\hline V. opulus L. & Opulus & $6.8 \pm .3$ & $6.5 \pm .4$ & $1.6 \pm .1$ & 1.0 & $99 \pm 19$ & $1-2$ & 2 & 0 & 0 & 0 \\
\hline $\begin{array}{l}\text { V. plicatum var. } \\
\text { tomentosum (Thunb.) }\end{array}$ & & $4.9 \pm .2$ & $3.2 \pm .1$ & $1.5 \pm .1$ & 1.5 & $54 \pm 26$ & 1 & & & & \\
\hline Miquel & Tomentosa & & & & & & & ? & 1 & 0 & 0 \\
\hline V. prunifolium L. & Lentago & $5.0 \pm .2$ & $3.5 \pm .2$ & $1.7 \pm .1$ & 1.4 & $94 \pm 26$ & $1-2$ & 1 & 0 & 0 & 0 \\
\hline V. rhytidophyllum & & $7.3 \pm .5$ & $4.4 \pm .1$ & $1.8 \pm .2$ & 1.7 & $213 \pm 43$ & $1-2$ & & & & \\
\hline Hemsley & Lantana & & & & & & & 1 & 1 & 0 & 0 \\
\hline V. sambucinum & & $7.5 \pm .7$ & $5.4 \pm .2$ & $2.3 \pm .1$ & 1.4 & $44 \pm 12$ & 1 & & & & \\
\hline Reinw. ex Blume & Megalotinus & & & & & & & 2 & 1 & 0 & 0 \\
\hline V. sargentii Koehne & Opulus & $6.9 \pm .4$ & $6.4 \pm .5$ & $1.6 \pm .2$ & 1.1 & $71 \pm 14$ & $1-3$ & 2 & 0 & 0 & 0 \\
\hline V. setigerum Hance & Succodontotinus & $8.4 \pm .4$ & $5.1 \pm .2$ & $1.7 \pm .1$ & 1.7 & $126 \pm 38$ & 1 & 2 & 1 & 0 & 0 \\
\hline V. sieboldii Miquel & Solenotinus & $6.9 \pm .2$ & $4.5 \pm .1$ & $2.5 \pm .1$ & 1.5 & $57 \pm 20$ & 1 & $?$ & 1 & 0 & 0 \\
\hline V. tinus L. & Tinus & $5.5 \pm .3$ & $4.3 \pm .7$ & $4.5 \pm .2$ & 1.3 & $81 \pm 26$ & $1-2$ & 2 & 1 & 2 & 0 \\
\hline V. veitchii Wright & Lantana & $6.9 \pm .6$ & $5.4 \pm .3$ & $1.8 \pm .1$ & 1.3 & $211 \pm 35$ & 1 & 1 & 1 & 0 & 0 \\
\hline
\end{tabular}

a $1=$ cells that are higher than wide (i.e., columnar or palisade-like); $2=$ cells that are as high as they are wide (i.e., cuboid) or wider than they are high (i.e., rectangular, with the longer axis parallel to the seed surface).

${ }^{\mathrm{b}} 0=$ absent; 1 = present.

c $0=$ absent; $1=$ rumination type $2 \mathrm{~A} ; 2=$ rumination type $2 \mathrm{~B}$.

to the seed surface, whereas those of type $2 \mathrm{~B}$ are not as organized and often split into smaller invaginations (fig. 5B, 5C). Finally, the invaginations of type $2 \mathrm{~A}$ do not touch, and this results in a small cavity between two adjacent invaginations, which is partially responsible for the lower amount of endosperm present (see above). Invaginations of type $2 \mathrm{~B}$ are generally touching, although cavities within the seed are not uncommon (fig. 5C).

Most species examined show type 1 rumination, which is mostly linked to the presence of dorsal and ventral grooves. Only V. dilatatum (Succodontotinus), V. carlesii (Lantana), and the Opulus and Lentago clades do not show any type of rumination. Type $2 \mathrm{~A}$ is restricted to $V$. clemensae (fig. $5 B$ ), whereas type $2 \mathrm{~B}$ is linked to the Tinus clade (fig. 5C). Type 3 is present in several clades, e.g., the Pseudotinus clade (fig. $5 B$ ) and a number of species belonging to the Solenotinus and Megalotinus clades (see "Megalotinus" and "Solenotinus" in "Species Groups").

Vasculature. All taxa studied have both a raphal and an antiraphal vascular bundle (fig. $4 A, 4 B, 4 F, 4 J$ ), which can be straight (fig. $4 F$ ) or undulating (fig. $4 J$ ). Both bundles are located at the margins of the seed (fig. $4 A, 4 B, 4 F, 4 J$; fig. 5A-5D). The length of the antiraphal bundle differs among species and can even differ within the same species. All vascular bundles are amphicribral (fig. 5E-5G). In general, the shape of the bundle is species specific (fig. $5 E-5 G$ ). However, the morphology 

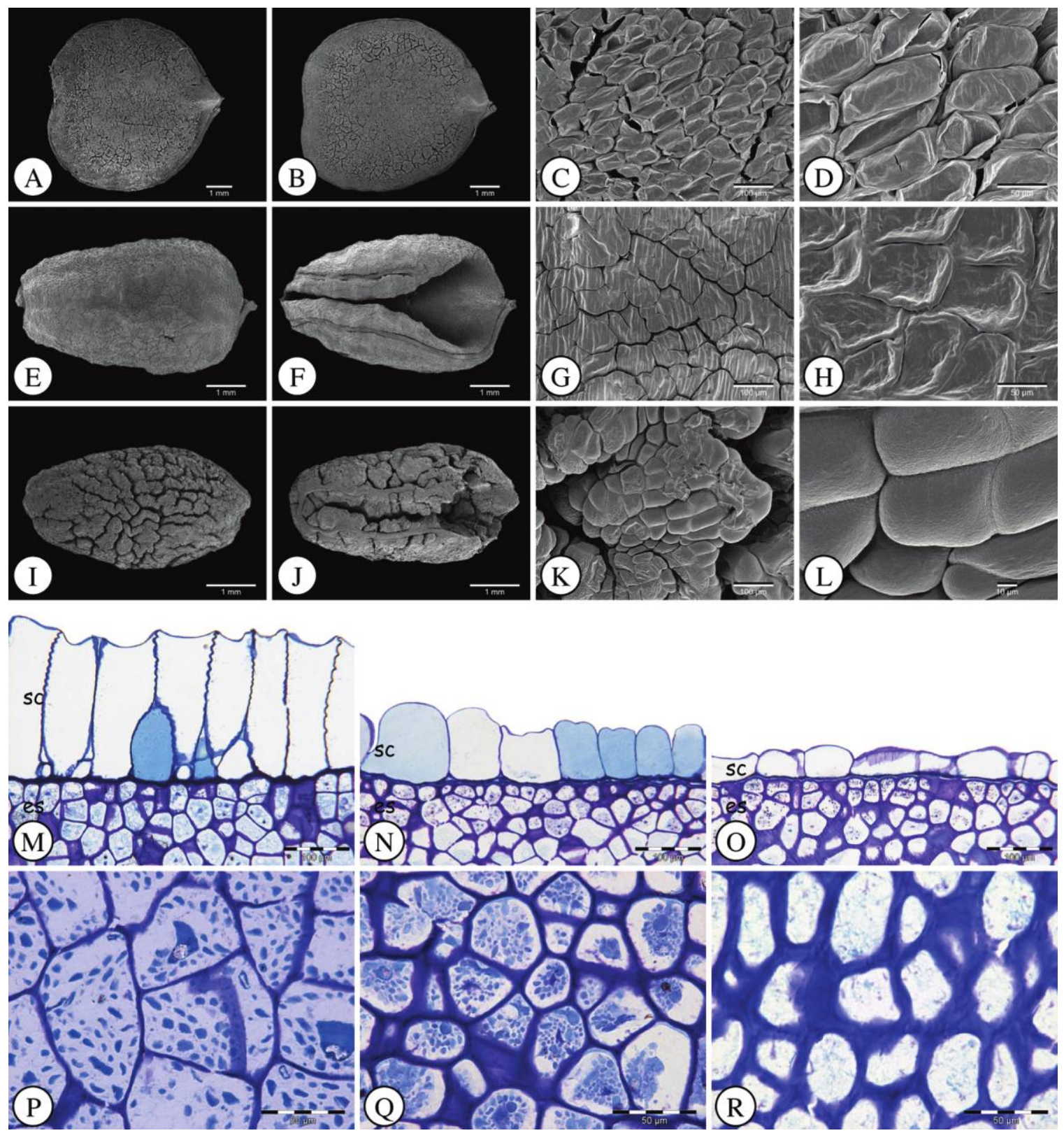

Fig. 4 Seed shape and seed coat morphology and anatomy in Viburnum. A-L, SEM; M-R, LM. A-L, Seed shape and seed coat morphology. A, $V$. opulus, dorsal view, visible raphe and antiraphe; $B, V$. opulus, ventral view; $C, D$, V. opulus, details of seed coat; E, V. sieboldii, dorsal view; $F$, $V$. sieboldii, ventral view, visible raphe and antiraphe; $G, H, V$. sieboldii, details of seed coat; $I$, V. davidii, dorsal view; J, V. davidii, ventral view, visible raphe and antiraphe; $K, L, V$. davidii, details of seed coat. $M-O$, Seed coat $(s c)$ anatomy (es = endosperm). $M$, V. veitchii, seed coat consisting of palisade cells; $N, V$. opulus, seed coat consisting of cuboid cells; $O, V$. dilatatum, seed coat consisting of rectangular cells. $P-R$, Endosperm anatomy: $P, V$. glabratum, large cells with thin cell walls; $Q, V$. rhytidophyllum, cell walls moderately thickened; $R, V$. sambucinum, cell walls heavily thickened.

and anatomy of the raphe and antiraphe often differ within the same species. Only spiral tracheids were observed (fig. 5G). Except for V. betulifolium, V. dilatatum, V. plicatum var. tomentosum, and V. rhytidophyllum, the raphal bundle and/ or the antiraphal bundle is characterized by a rhexigenous cavity (fig. $5 E-5 G$ ). In a few cases, the raphal and antiraphal bundles show an undulating pattern.

Crystals. Calcium oxalate crystals in the endocarp and mesocarp are common within Viburnum. Except for the Len- tago and Oreinodontotinus clades, V. davidii (Tinus), V. luzonicum (Succodontotinus), and V. cotinifolium (Lantana), all species examined are characterized by crystals in the endocarp and/or mesocarp. The cells occur as idioblasts (e.g., V. dilatatum), clusters of cells (e.g., V. sambucinum, V. rhytidophyllum; fig. $5 I$ ), or a more or less continuous layer of crystal-containing cells ( $V$. tinus). Mostly, the crystals are found near the border of endocarp and mesocarp (fig. 5I). The nature of the crystals, i.e., endocarp or mesocarp, is therefore not always clear. 


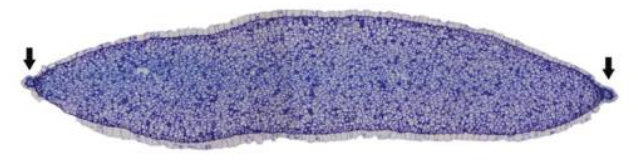

(A) $-\infty$ ronom -

(B)
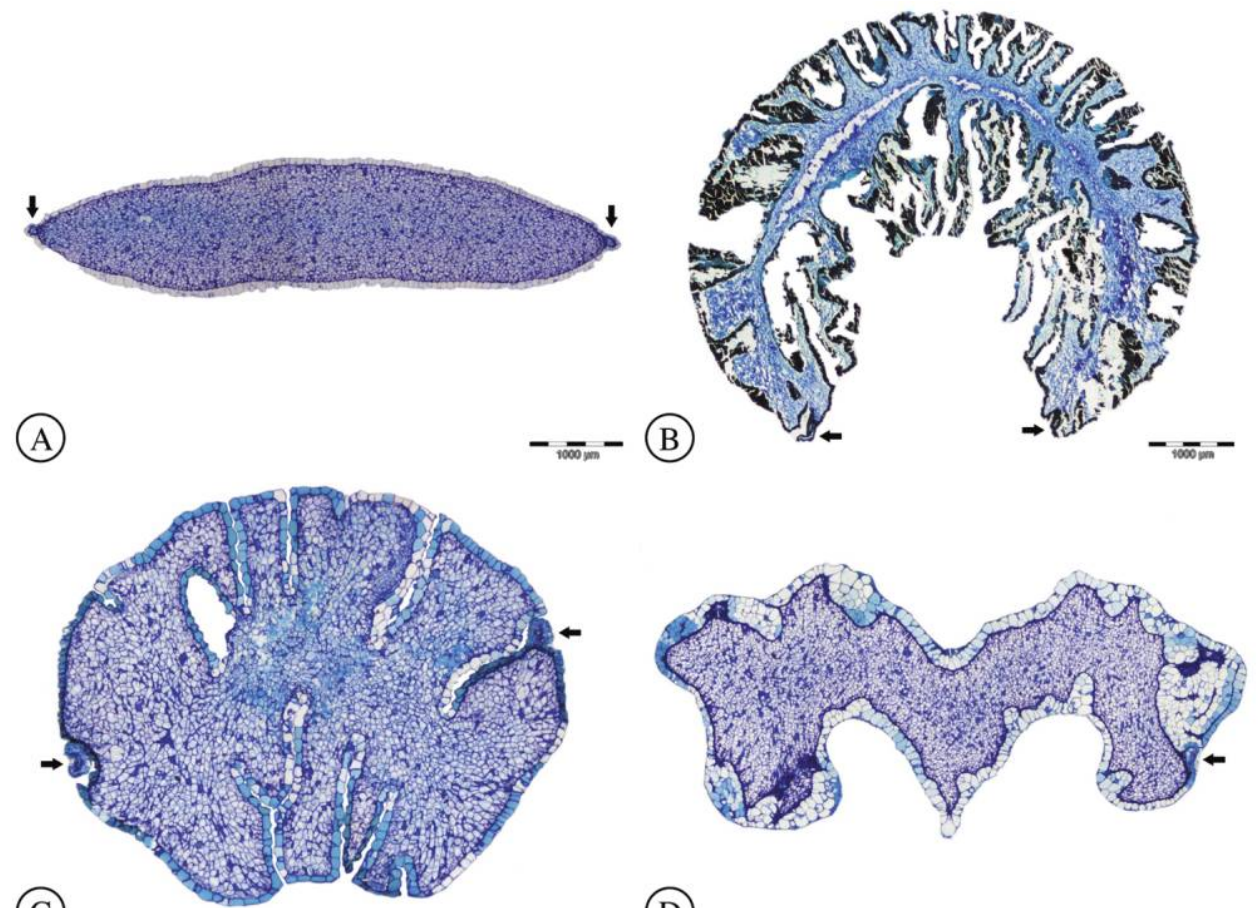

(C) $-1000 \mathrm{~m}-$ (D)
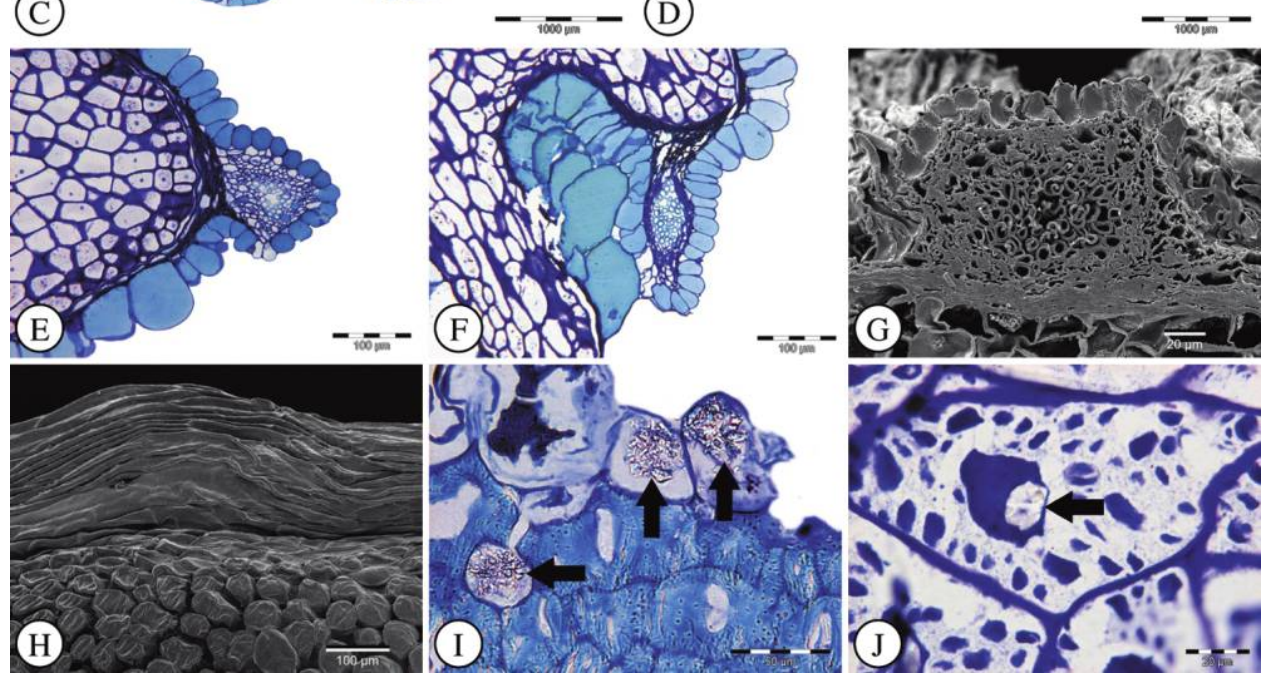

Fig. 5 Rumination types, seed vasculature and crystals in Viburnum. A-E, H, I, J, LM; F, G, SEM. A-D, Rumination types and position of vascular bundles (arrows). A, V. sargentii, no rumination; B, V. clemensae, type 1 and type 2A rumination; C, V. tinus, type 1 and type 2B rumination; $D, V$. lantanoides, type 1 and type 3 rumination. $E-H$, Shape and size of vascular bundles and morphology of raphe. E, V. opulus, circular vascular bundle with rhexigene cavity; $F, V$. cotinifolium, elliptical vascular bundle with rhexigene cavity; $G$, V. lantana, elliptical vascular bundle with spiral tracheids; $H, V$. veitchii, raphal morphology differs from seed coat. $I, J$, Crystals in endocarp and endosperm. $I$, V. rhytidophyllum, druses in endocarp; J, V. glabratum, small, amorphous crystals in endosperm.

One to several small, amorphous calcium oxalate crystals mark the endosperm of Viburnum (fig. 5J; see "Endosperm" above). The peripheral cell layers of the endosperm are anatomically distinct from the rest of the endosperm (see "Endosperm" above) and do not contain these crystalloid inclusions.

Embryo morphology. Embryo morphology of 12 species was examined. Following Martin's definition of embryo size (Martin 1946), embryos of Viburnum are small, which means that the volumetric ratio of embryo and endosperm is less than one-quarter. Embryo length ranges from 0.48 to $1.30 \mathrm{~mm}$, em- bryo width from 0.24 to $0.56 \mathrm{~mm}$, and embryo thickness from 0.20 to $0.38 \mathrm{~mm}$. The embryo is linear (being several times longer than broad) and straight and is unaffected by seed rumination. Two straight, well-developed cotyledons are present.

\section{Species Groups}

The following paragraphs briefly summarize the key endocarp and seed characteristics of the individual species groups defined by Winkworth and Donoghue (2005). In parentheses 
is the number of species belonging to the group, followed by the number of species included in our study.

Lobata (3/1). Pyrenes and seeds of V. acerifolium are discoid in overall shape, cordate to ovate in dorsal view, and compressed, undulate in cross section. Toward the exterior, the sclereids of the endocarp are only slightly sclerified. $\mathrm{Cu}-$ boid to rectangular parenchymatous cells make up the seed coat. The walls of the endosperm cells are moderately thickened. Endocarp shape results in type 1 ruminate seeds.

Succodontotinus (36/10). The Succodontotinus clade is diverse with respect to pyrenes and seeds. Except for V. phlebotrichum and V. sempervirens, which tend to have globoidlike pyrenes, most species have discoid pyrenes. The shape in dorsal view is highly variable and ranges from circular and elliptical to ovate, clavate, fusiform, and cordate. In cross section, compressed, undulate pyrenes and seeds are common. Only V. phlebotrichum and V. sempervirens deviate from this pattern by having pyrenes and seeds that are circular to elliptical in cross section. Both sclereids and fibers are heavily sclerified (i.e., have small cell lumina), resulting in a rigid endocarp. A single layer of elongated, spindle-shaped fibers makes up the inner layer of the endocarp. Viburnum luzonicum somewhat deviates from this pattern by having fibers with slightly undulating lateral margins. The seed coat is made up of cuboid to rectangular cells. All species are characterized by type 1 rumination.

Megalotinus (18/2). Pyrenes and seeds of the Megalotinus clade are discoid in overall shape and compressed, undulate in cross section. The shape in dorsal view is subject to considerable variation and ranges from clavate and fusiform $(V$. cylindricum) to ovate (V. glaberrimum), elliptical ( $V$. punctatum), and cordate (V. ternatum). Viburnum cylindricum and $V$. sambucinum differ in a few aspects. (1) Regarding seed coat anatomy, V. cylindricum has long, palisade-like cells, while $V$. sambucinum is marked by cuboid and rectangular seed coat cells. (2) Another prominent difference is the cell wall thickness of the endosperm cells. Viburnum cylindricum has moderately thickened cell walls, whereas $V$. sambucinum is marked by heavily thickened cell walls. (3) Furthermore, the rigidity of the endocarp differs considerably. Viburnum cylindricum has a thin, moderately sclerified endocarp, whereas the endocarp of $V$. sambucinum is thick and built of heavily sclerified cells. (4) Finally, the fibers of V. sambucinum are slightly scrobiculate, or pitted. This is the result of pit canals that do not make contact with pit canals of an adjacent cell but instead are covered with a thin layer of sclerified wall. Type 1 rumination is present in all species belonging to Megalotinus. Type 3 rumination, however, is restricted to V. lepidotulum and V. lutescens. These species are characterized by local proliferations of the seed coat, resulting in invaginations and endosperm rumination.

Tinus (7/2). The Tinus clade is marked by globoid to cylindrical pyrenes and seeds (fig. 4I, 4J). Shape in cross section is circular to elliptical, with one to several grooves. Shape in dorsal view ranges from circular, elliptical, or ovate to fusiform or lacryform. The fruits of $V$. tinus, $V$. davidii, and V. cinnamomifolium are typically dry because of the presence of only a few layers of small exocarp and mesocarp cells. Moreover, $V$. cinnamomifolium has a hard and rigid fruit surface because of sclerification of the exocarp cells.
Type 2B rumination sets the Tinus clade apart from all other clades (fig. 5C). The seed coat consists of a single cell layer surrounding the ruminate endosperm. The rumination does not affect embryo morphology.

Viburnum davidii is marked by the occurrence of cells that differ significantly from those found in the rest of Viburnum, i.e., cells with undulating cell walls and only moderately elongated (fig. $3 K$ ). The cells are slightly flattened, as are the fibers of $V$. cinnamomifolium. The latter species differs from $V$. davidii and $V$. tinus with respect to the inner endocarp surface. The seed coat sculpts the inside of the endocarp during seed development, and therefore the pattern of spindle-shaped cells is absent (cf. V. odoratissimum and V. glabratum). Finally, the fibers of V. tinus are slightly scrobiculate, or pitted (cf. "Megalotinus" in "Species Groups").

Oreinodontotinus (39/1). The taxa belonging to the Oreinodontotinus clade are found in three main regions: eastern South America, eastern Mexico, and eastern North America. Pyrene and seed shape differ, depending on the region where the species occur. Globoid-like pyrenes and seeds mark species found in eastern South America. The shape in cross section is circular to elliptical and notched, and the shape in dorsal view is mostly lacryform or fusiform. In eastern Mexico, species belonging to the Oreinodontotinus clade have curved, discoid pyrenes and seeds. The shape in cross section is curved, nonundulate, and in dorsal view it is elliptical to ovate or slightly fusiform. Species found in eastern North America are characterized by curved, discoid pyrenes and seeds. Shape in cross section is curved, undulate or curved, nonundulate, and the shape in dorsal view is mostly cordate or ovate (sometimes circular or fusiform). The endosperm of V. glabratum typically has large cells with thin cell walls. The seed coat is fairly thin and made up of cuboid to rectangular cells. Only type 1 rumination is present.

Mollodontotinus (7/0). Species belonging to the Mollodontotinus clade have discoid pyrenes and seeds. The shape in dorsal view varies from elliptical or ovate to fusiform, and the shape in cross section is compressed, undulate. Only type 1 rumination is present.

Opulus (5/2). Pyrenes and seeds of the Opulus clade are discoid in overall shape and compressed, nonundulate in cross section. The shape in dorsal view is typically cordate (e.g., V. opulus and V. trilobum). Drupes of the Opulus clade are characterized by a well-developed, succulent, sour-tasting mesocarp. The sclereids toward the exterior are only a little sclerified. A single cell layer of fibers constitutes the inner endocarp layer. Endocarp crystals occur as idioblasts throughout the endocarp. The parenchymatous seed coat is composed of a single layer of mostly cuboid cells. Rumination is absent in the Opulus clade.

Lantana (14/6). Members of the Lantana clade have discoid pyrenes and seeds that are compressed, undulate in cross section. The shape in dorsal view varies significantly and ranges from circular, elliptical (V. buddleijifolium), or ovate to clavate, cordate (V. lantana), or sometimes fusiform (V. rhytidophyllum). Pyrenes and seeds with two dorsal grooves and three ventral grooves typically mark the Lantana clade. This feature is especially obvious in subsection Viburnum, as defined by Hara (1983). A single cell layer of slender fibers constitutes the inner endocarp layer, and together with the adjacent, heavily sclerified sclereids, a rigid endocarp is formed. 
Within Lantana, little variation occurs regarding pyrene sculpture. Mesocarp cells are isodiametric, except for V. rhytidophyllum, which has slightly elongated mesocarp cells. Except for V. rhytidophyllum and V. cotinifolium, all species studied contain crystals in the endocarp or at the border of endocarp and mesocarp. The crystal-containing cells occur either as idioblasts or as a cluster of cells, each containing a single crystal.

All species accommodated in Lantana are typified by type 1 rumination. Because type 1 rumination is closely associated with the pattern of grooves, it is most obvious in Hara's subsection Viburnum. The seed coat consists of a thick layer of large, elongated (i.e., palisade-like) cells, and in some species a second layer of small, compressed cells is present.

Lentago (7/2). The Lentago clade is marked by discoid pyrenes and seeds. Except for V. nudum and V. obovatum, all species of the Lentago clade have seeds and pyrenes that are compressed, nonundulate in cross section. The shape in dorsal view ranges from circular (e.g., V. lentago), elliptical, or ovate to cordate or fusiform (e.g., V. prunifolium). Lentago accommodates the largest pyrenes observed in this study (table 1). The endocarp is thick but nonetheless flexible. The sclereids and fibers are only moderately sclerified (e.g., V. lentago).

The seed coat is composed of a single layer of palisade-like cells. The seeds of the Lentago clade are nonruminate, with the exception that V. nudum and V. obovatum, which are positioned at the base of the Lentago clade, have type 1 ruminate seeds. The presence of grooves sets apart the latter species from the rest of the clade.

Pseudotinus (4/1). Species belonging to the Pseudotinus clade have curved, discoid pyrenes and seeds. The shape in cross section is curved, undulate, whereas the shape in dorsal view ranges from circular, elliptical, or ovate to cordate or fusiform. The endocarp of $V$. lantanoides differs slightly from the rest of the species examined. A thick, robust endocarp typifies V. lantanoides. The most striking difference, however, is the number of fibrous layers, which can be as many as five. However, the transition between fibers and sclereids is not always obvious.

The seed coat consists of large, cuboid to palisade-like cells, which can be multilayered in places. A well-developed second layer of much smaller seed coat cells is present. Type 1 rumination is obvious. Type 3 rumination is present as well and causes the endosperm to be ruminate.

Solenotinus (26/2). Pyrenes and seeds are curved and discoid in overall shape, curved, undulate in cross section, and clavate in dorsal view. Endocarp thickness varies significantly within the clade, as V. sieboldii and V. odoratissimum show (table 1). The inner endocarp surface of V. odoratissimum deviates from the pattern observed in the other members of the clade; i.e., the seed coat cells shape the inner endocarp surface, leaving an imprint of the seed coat instead of the typical outline of the fibers. Crystal-containing idioblasts are present in the endocarp of $V$. odoratissimum.

The seed coat is composed of cuboid ( $V$. sieboldii) to slightly palisade-like cells ( $V$. odoratissimum). Endosperm cell walls are rather thick in $V$. sieboldii and much less sclerified in $V$. odoratissimum.

Seeds of the Solenotinus clade are all type 1 ruminate. In addition, a number of species ( $V$. odoratissimum, V. brachy- botryum, V. henryi, V. awabuki, and V. farreri) produce seeds that are type 3 ruminate. Local proliferation of the seed coat is characteristic in these cases.

Tomentosa (2/1). Overall pyrene and seed shape is discoid, whereas the shape in cross section is compressed, undulate. At the base part of the seed, however, the margins curve slightly inward ventrally. We scored this condition as being compressed, undulate because these margins differ from those of the Pseudotinus clade, for example, which are truly curved. The shape in dorsal view ranges from circular or elliptical to ovate. The flattened pyrenes are marked by two dorsal and three ventral grooves. Endocarp cells are heavily sclerified, resulting in a rigid structure. Crystal-containing idioblasts are present in the endocarp.

Cuboid to rectangular cells make up the relatively thin seed coat. Only type 1 rumination is present. Cells of the endosperm are moderately thickened.

Viburnum urceolatum. Results for V. urecolatum are based solely on camera lucida drawings and SEM observations of the endocarp. Pyrenes and seeds of V. urceolatum are discoid in overall shape, compressed, undulate in cross section, and elliptical or ovate to slightly cordate in dorsal view. A single cell layer of spindle-shaped, laterally compressed fibers makes up the inner endocarp surface. The adjacent sclereids are moderately sclerified. Seeds of V. urceolatum are type 1 ruminate and have endosperm cells with moderately thickened cell walls.

Viburnum clemensae. Drupes of $V$. clemensae have a thin, dry pericarp. The mesocarp is thin and is composed of small cells, resulting in a smooth endocarp surface. The species is characterized by globoid to cylindrical pyrenes that are curved, nonundulate in cross section. The lateral margins are ventrally curved inward and touch in the middle of the ventral surface.

In addition to rumination type $1, V$. clemensae is marked by rumination type $2 \mathrm{~A}$. This type of rumination separates the species from all other species examined. The inner surface of the endocarp is sculpted by both the seed coat and the presence of the fibers of the endocarp. The fibers are slightly scrobiculate, or pitted (cf. "Megalotinus" and "Tinus" in "Species Groups").

Generally, the seeds do not fill the entire space provided by the surrounding endocarp. Since only herbarium specimens were used, this could be due to the drying process. The seeds are dark brown to almost black. The seed coat is composed of a single layer of large, cuboid to rectangular cells. Amorphous calcium oxalate crystals occur only in the center of the endosperm, not in the invaginations.

\section{Discussion}

\section{Evolutionary Implications}

In order to infer the evolution of endocarp and seed characters in Viburnum, we have taken advantage of the most recent phylogenetic analyses based on multiple molecular (chloroplast and nuclear) markers (Winkworth and Donoghue 2005). Using MacClade 4.0 (Maddison and Maddison 2002), we have parsimoniously optimized a set of key characters derived from the anatomical and morphological data presented above. The mapping of characters was carried out using a phylogenetic tree that corresponds in topology to the 
summary presented by Winkworth and Donoghue (2005; fig. $5 B)$. Our sampling and the sampling of Winkworth and Donoghue (2005) have 17 species in common, and only these species were included in the parsimony optimization analyses. This has resulted in a sampling of every species group recognized by Winkworth and Donoghue (2005), with the exception of Oreinodontotinus and Mollodontotinus.

After examining the results of the parsimony optimization analyses, we included the species omitted from those analyses, to give additional support and to clarify phylogenetic relationships and evolutionary trends. The latter species were assigned to species groups of Winkworth and Donoghue (2005) on the basis of morphological and anatomical data. For example, we sampled V. rhytidophyllum, V. cotinifolium, $V$. veitchii, and V. bitchiuense for endocarp and seed characters, but these were not included in the molecular phylogenetic analyses of Winkworth and Donoghue (2005). These four species were placed in the Lantana clade of Winkworth and Donoghue, which corresponds to the traditionally recognized section Viburnum. This placement is justified not only by their assignment to section Viburnum by Hara (1983) and others (Donoghue 1983a, 1983b; Winkworth and Donoghue 2005) but also by the set of morphological traits that marks this complex of species: the presence of naked buds and stellate trichomes expressed in the context of an entirely orthotropic growth pattern (Donoghue 1981), as well as their distinctive pollen exine morphology (Donoghue 1985). Likewise, $V$. betulifolium, V. dasyanthum, V. foetidum, V. fordiae, $V$. hupehense, V. ichangense, V. luzonicum, and V. setigerum were added to the Succodontotinus clade of Winkworth and Donoghue on the basis of Hara's placement of these species in subsection Odontotinus of section Odontotinus, which includes the red-fruited species of Asia, typically with dentate leaf margins. Viburnum opulus was included in the Opulus clade of Winkworth and Donoghue on the basis of its assignment to the traditional section Opulus, which is well characterized by the fusion of the outer set of bud scales, the presence of sterile, enlarged marginal flowers in the inflorescences (which specifically unites this species with V. trilobum and $V$. sargentii), and the Opulus-type growth pattern of Donoghue (1981). We placed the Latin American species V. glabratum in the Oreinodontotinus clade of Winkworth and Donoghue (2005) on the basis of its placement in the traditional section Oreinotinus, which contains all species from Central and South America. Finally, we assigned both $V$. sambucinum and V. cylindricum to the Megalotinus clade of Winkworth and Donoghue (2005). This is based on their traditional placement in the largely Southeast Asian section Megalotinus (Hara 1983) and their shared possession of evergreen leaves with entire margins.

Several endocarp and seed characters provide a distinct phylogenetic signal that helps understand the morphological evolution of Viburnum regarding fruits and seeds. The following paragraphs discuss four characters in detail. Two characters are related to the endocarp: (1) shape in cross section and grooving and (2) maximum number of fibrous cell layers. The remaining two characters are associated with the seed: (3) seed coat cell shape and size and (4) seed rumination. Several other variables noted above are potentially of evolutionary interest and are discussed briefly. The discussion of every character is split into two sections: (1) the results of the parsimony optimization analyses and (2) the inclusion of those species that were omitted from the phylogenetic analyses (see "Material and Methods").

1. Pyrene shape in cross section and grooving (fig. 6). The variation observed throughout Viburnum resulted in the recognition of five character states reflecting the shape and grooving of the endocarp (see "Results"). The possibility of scoring dorsal and ventral grooving as separate characters, distinct from the shape in cross section, was considered. However, this would have the effect of mixing compressed, curved, and circular forms without grooves into a single state regarding the presence of grooves (thereby assuming homology) and therefore bias against a scenario in which the loss of grooves occurred independently in the context of different shapes. Furthermore, scoring shape in cross section and grooving separately creates two characters that overlap considerably.

The plesiomorphic condition within Viburnum is equivocal, which is partly due to the condition found in V. clemensae, i.e., curved, nonundulate. Parsimony optimization implies that the ancestor that gave rise to the species after the initial split with $V$. clemensae was characterized by compressed, undulate pyrenes. From this condition, four initial shifts are inferred to have occurred. (1) At the origin of both the Opulus clade and the Lentago clade (two separate events), the grooves on both the dorsal and ventral sides appear to have been lost. (2) At the base of the Pseudotinus clade, one shift from compressed, undulate to curved, undulate took place. (3) One shift from compressed, undulate to curved, nonundulate took place, i.e., at the base of the Solenotinus clade. (4) Finally, the Tinus clade is characterized by a shift to circular (and elliptical), notched pyrenes. Our results indicate this shift took place at the origin of the Tinus clade.

We now discuss a number of hypotheses based on our broader sampling as well as additional species (M. J. Donoghue, unpublished data) for which information about pyrene shape was available. In the case of Lentago, it is likely that the shift from compressed, undulate to compressed, nonundulate pyrenes took place within the clade, because V. obovatum and $V$. nudum show some grooving. Furthermore, within the Solenotinus clade, there may well have been an intermediate curved, undulate condition (cf. Pseudotinus) in the transition from compressed, undulate to curved, nonundulate pyrenes. In addition, the inclusion of additional species has allowed us to study the Oreinodontotinus clade with respect to pyrene shape. In the Oreinodontotinus clade, three shifts are likely to have taken place with compressed, undulate pyrenes as the starting point: (1) a shift to curved, undulate pyrenes, (2) a shift to curved, nonundulate pyrenes, and (3) a shift to circular (or elliptical), notched pyrenes (cf. Tinus). An expanded sampling and more resolved phylogeny are required to confidently locate the shifts in this particular clade. However, additional evidence within Oreinodontotinus favors the view that this clade started with curved, undulate endocarps in the eastern United States and eastern to central Mexico and transitioned, possibly through curved, nonundulate forms, to the circular, grooved endocarps characteristic of the Central and South American species.

It is interesting to note that although there have been multiple changes in endocarp shape, these have resulted in the 


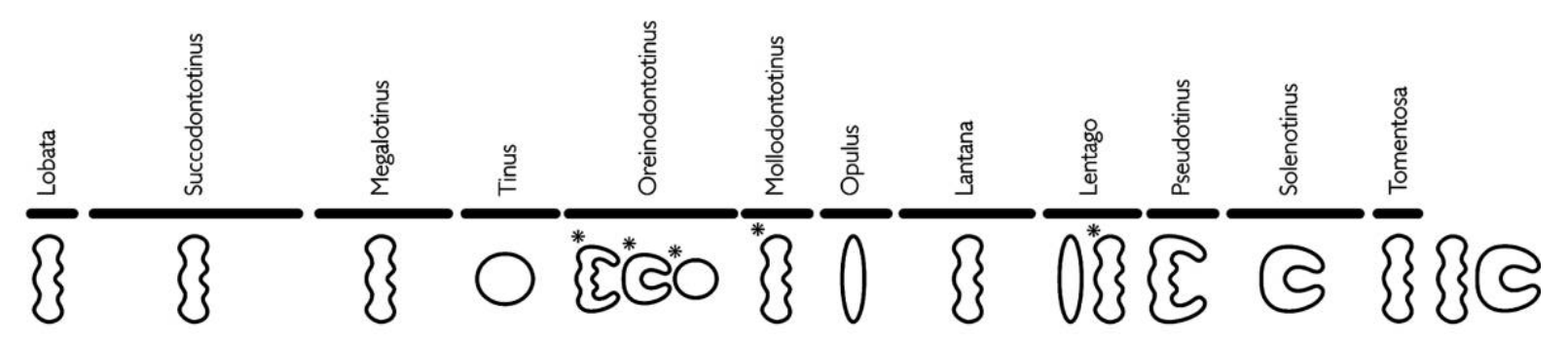

篁

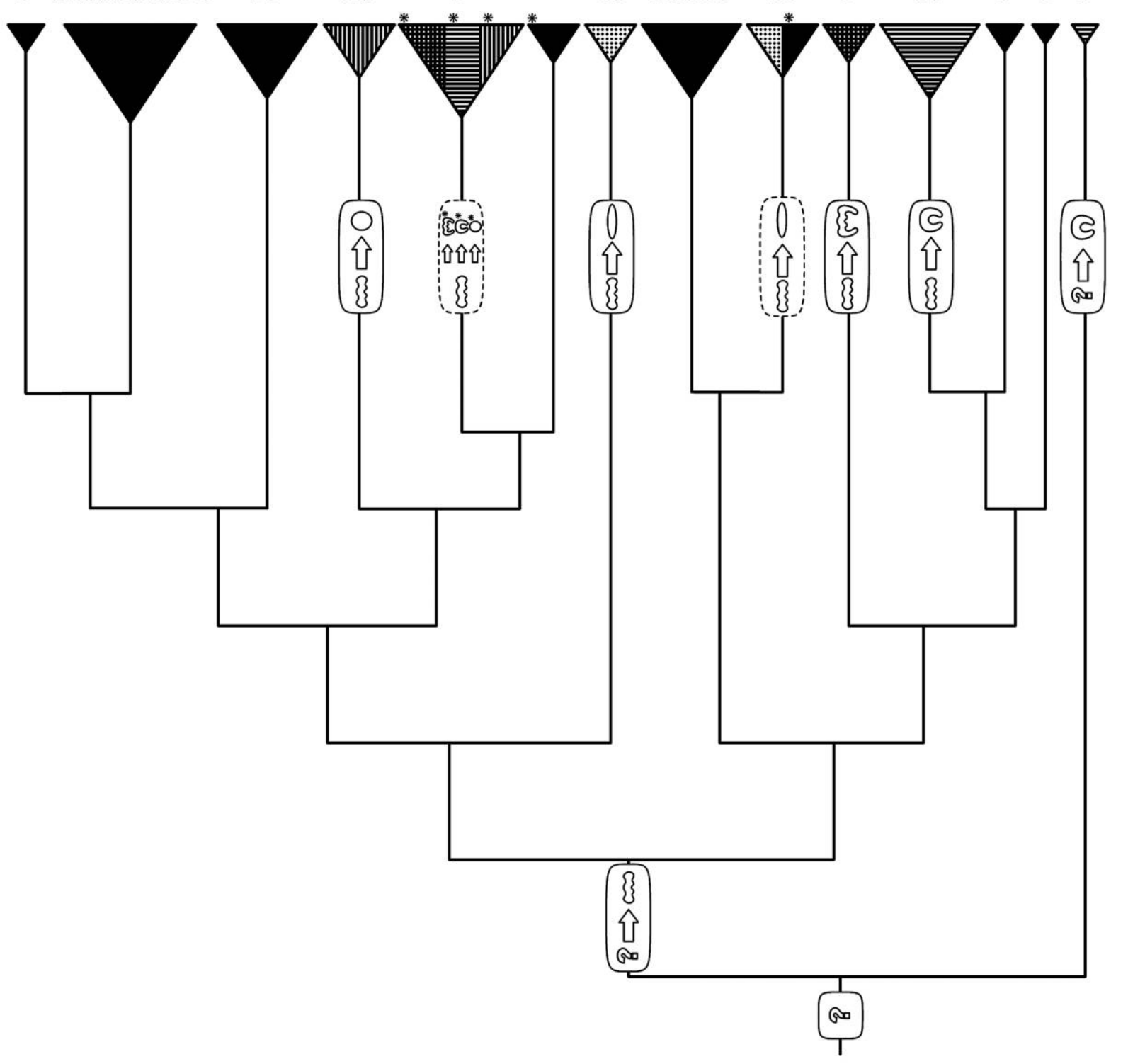

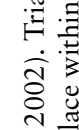

है

त्रु के

$\sum_{0}^{\pi}$

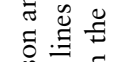

莺

픈

워

苋苛

$\sum^{\pi} \stackrel{n}{n}$

言岕

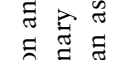

总选

.

苔嵌芯

謌节

言

की के

क

की प्र

. गु

कू 矛

.0

岛 定

के సै

छ তี

ฝิ สิ

कै ป ป

ปั $\cong$

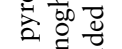

पै

总苛

㝳 힌

0.

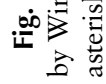


independent acquisition of several particular endpoints, namely, flattened, ungrooved endocarps and circular, ventrally grooved endocarps (possibly via curved and undulate forms). Several theoretically possible transitions apparently never took place, such as a direct shift between compressed, nonundulate and circular-grooved. Also, we infer no instances of reversal from any of these derived states back to the ancestral condition. Overall, we see a trend from undulate to nonundulate forms and from compressed to curved and circular forms.

Examination of the full range of variation found among the compressed, undulate forms suggests that it may ultimately be possible to distinguish between several different forms and that these may be characteristic of different clades. For example, members of Lobata and Succodontotinus (all but V. acerifolium found in the Old World), and even of Megalotinus, tend to have endocarps in which the lateral edges (seen in cross section) are pointed. This contrasts with our observations that these edges are rounded in Mollodontotinus and in basal Oreinodontotinus, both of which are found in the New World. It would be useful to pursue these more subtle distinctions in the context of a thorough landmark-based morphometric analysis.

2. Maximum number of fibrous cell layers (fig. 7). The number of fibrous cell layers that form the inner layer of the endocarp (see "Endocarp structure" above), is quite variable within Viburnum. In several cases, the number of fibrous layers varies within a single species as well. The maximum number of fibrous layers, however, appears to fall into two categories: (1) a single cell layer and (2) two or more cell layers. This division is justified by the observation that within the second state there is notable variation, often within an individual endocarp, between two and three or more layers, with up to five layers in $V$. lantanoides. This character shows considerable homoplasy, involving multiple shifts to multiple layers of fibers and possibly shifts from multiple layers to just one. In the current sampling, it appears V. clemensae and the Lantana, Pseudotinus, and Solenotinus clades are characterized by multiple layers, whereas V. urceolatum and the Lentago, Tomentosa, Opulus, Oreinodontotinus, Succodontotinus, and Lobata clades have only a single layer of fibers.

From maximum parsimony, within Imbricotinus, two shifts from a single layer of fibers to multiple layers are inferred to have taken place. The Tinus clade is marked by the presence of both states; i.e., V. tinus has one fibrous layer, whereas $V$. davidii has more. Moreover, V. davidii also has highly unusual elongated cells with undulating cell walls instead of fibers (fig. $3 K)$. Whether this condition is unique to V. davidii or is found in other Tinus members deserves additional study.

From our broader sampling, several conclusions can be drawn. First, the Megalotinus clade is marked by the presence of both states (cf. Tinus); i.e., V. cylindricum is marked by multiple layers of fibers (i.e., two), whereas V. sambucinum has only a single fibrous layer. Second, the innermost layer of the endocarp of $V$. cinnamomifolium (only the morphology was studied), belonging to the Tinus clade, is built of a single layer of fibers (cf. V. davidii). In contrast to $V$. davidii, the innermost layer is composed of fibers and not the elongated cells described above.

Although our sampling of Megalotinus is modest, our results give an indication that Megalotinus does not form a clade (see "Results"). If Megalotinus does form a clade as sampling is expanded in future phylogenetic studies, this may represent another independent shift to more layers (see above).

The pattern of shifts within the clade containing Lantana, Lentago, Pseudotinus, Solenotinus, Tomentosa, and V. urceolatum is less obvious. The condition of the ancestor giving rise to this clade is equivocal. The different character states are scattered, although it must be noted that all species groups are marked by a single condition, i.e., a single layer of fibers or multiple layers.

The endocarp of $V$. clemensae is built of multiple layers of fibers, and this, in part, results in the equivocality of the plesiomorphic condition of Viburnum. In various species, the difference between fibers and sclereids is not obvious (e.g., $V$. lantanoides). A gradual transition from fibers to sclereids was observed in a number of cases, and it is therefore sensible to consider whether a shift from a single layer of fibers to multiple layers is a major shift that has taken place several times during the evolution of Viburnum.

3. Seed coat cell shape and size (fig. 8). From the diversity of seed coat cell shapes and sizes documented above, we recognize a single binary character distinguishing between seed coats with a layer of large, elongated (columnar or palisadelike) cells that are clearly taller than they are wide (fig. 4M) and those with a layer of smaller, cuboid to rectangular cells that are equal in cell height and width (fig. $4 N$ ) or wider than they are high (fig. 4O).

The results of the parsimony optimization analyses indicate that the plesiomorphic condition within Viburnum is the elongated cell type. Two shifts to the derived smaller cell type are inferred to have taken place, as well as a single reversal from the smaller cell type to the elongated cell type. (1) At the base of the suprasectional clade containing the Lentago, Lantana, Pseudotinus, Solenotinus, and Tomentosa clades, the first shift occurred. (2) Within the same clade, in the Tomentosa clade in particular, a reversal to the elongated cell type happened. (3) A second shift to the elongated cell type took place at the base of or within the Megalotinus clade.

Our broader sampling indicates that the second shift to the elongated cell type took place within the Megalotinus clade and not at the base of the clade. Viburnum sambucinum has small cells characteristic of the rest of Imbricotinus, whereas $V$. cylindricum has notably elongated cells comparable to those found in the other major clade. This adds support to our hypothesis that the Megalotinus clade might not be monophyletic (see "Maximum number of fibrous cell layers" above). It must be noted, however, that the cells of $V$. cylindricum are slightly different from those observed in the Lentago, Lantana, Pseudotinus, and Solenotinus clades. Viburnum cylindricum has seed coat cells that are much more slender, i.e., many times taller than they are wide.

4. Seed rumination (fig. 9). In the discussion of seed rumination, type 1 is left out because it is correlated with, and therefore phylogenetically overlaps, pyrene shape in cross section and grooving (see "Rumination" above). In the following paragraphs, "rumination" refers to types 2 and 3.

The plesiomorphic condition within Viburnum is equivocal. From parsimony optimization, ruminate seeds seem to have evolved four or five times, depending on the ancestral character state. The basal split with $V$. clemensae is marked by uncertainty. As long as the ancestral character state of 


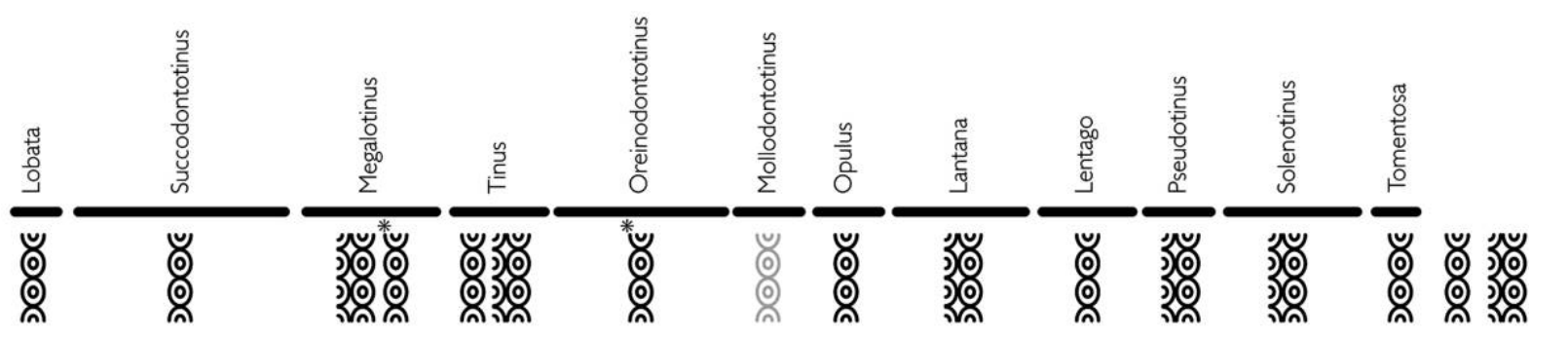

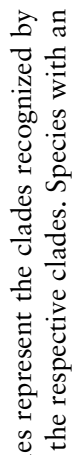

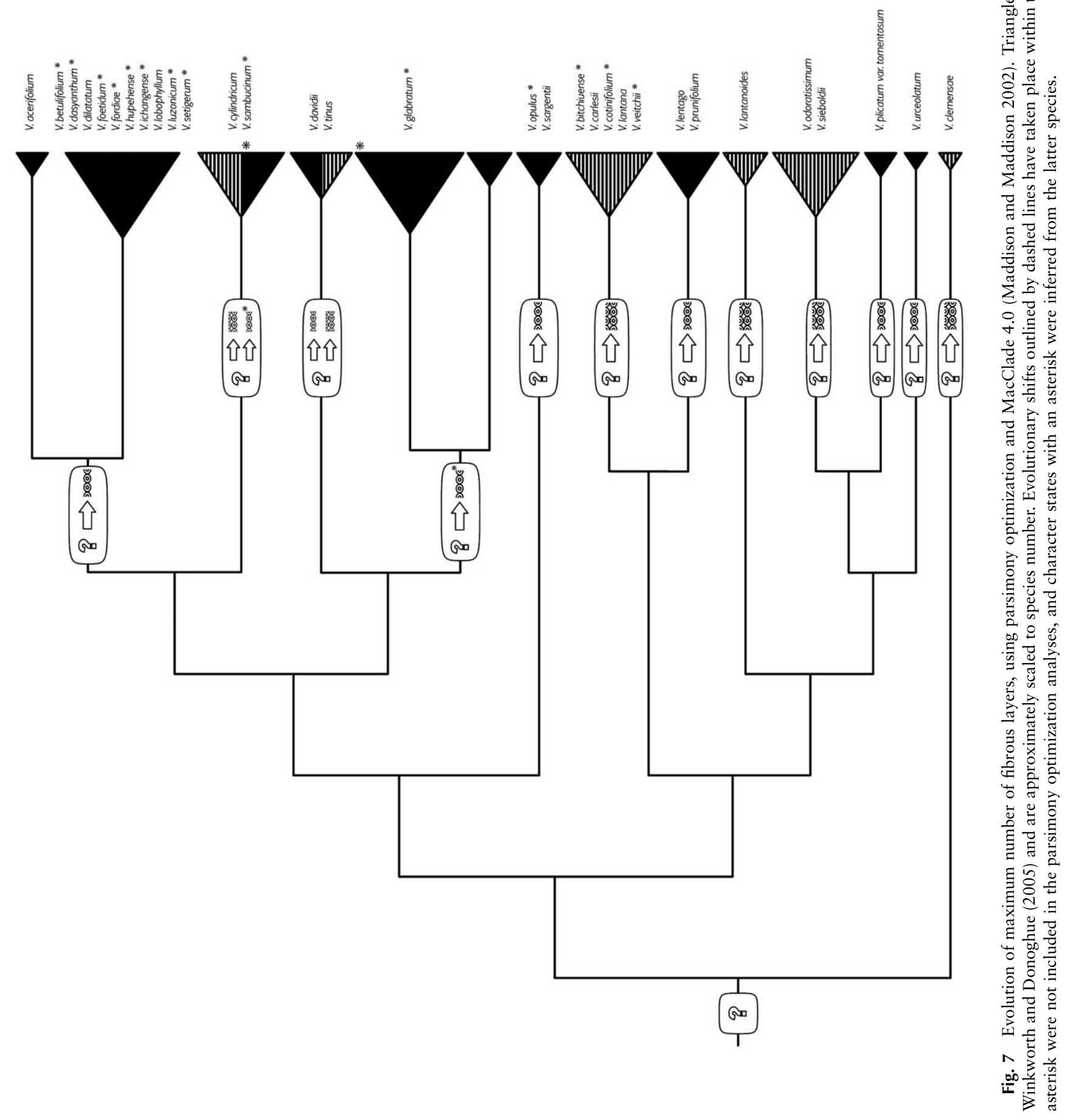




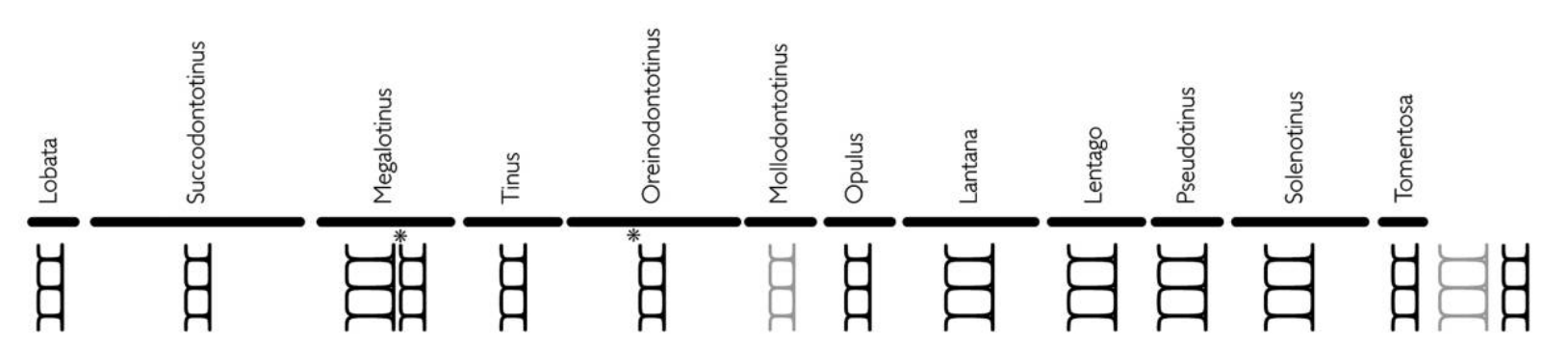

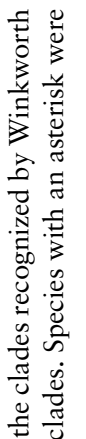

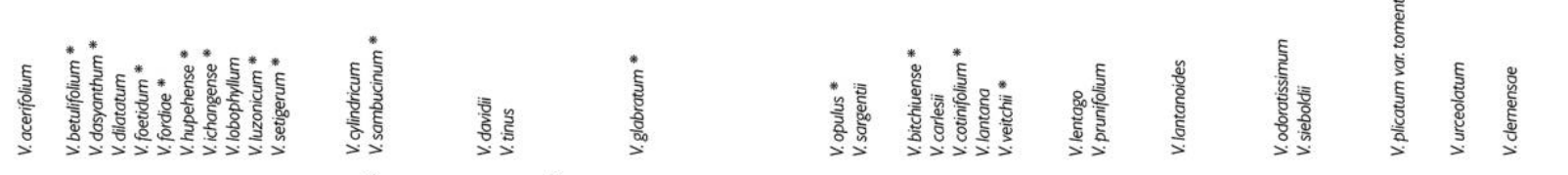

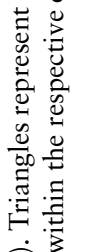

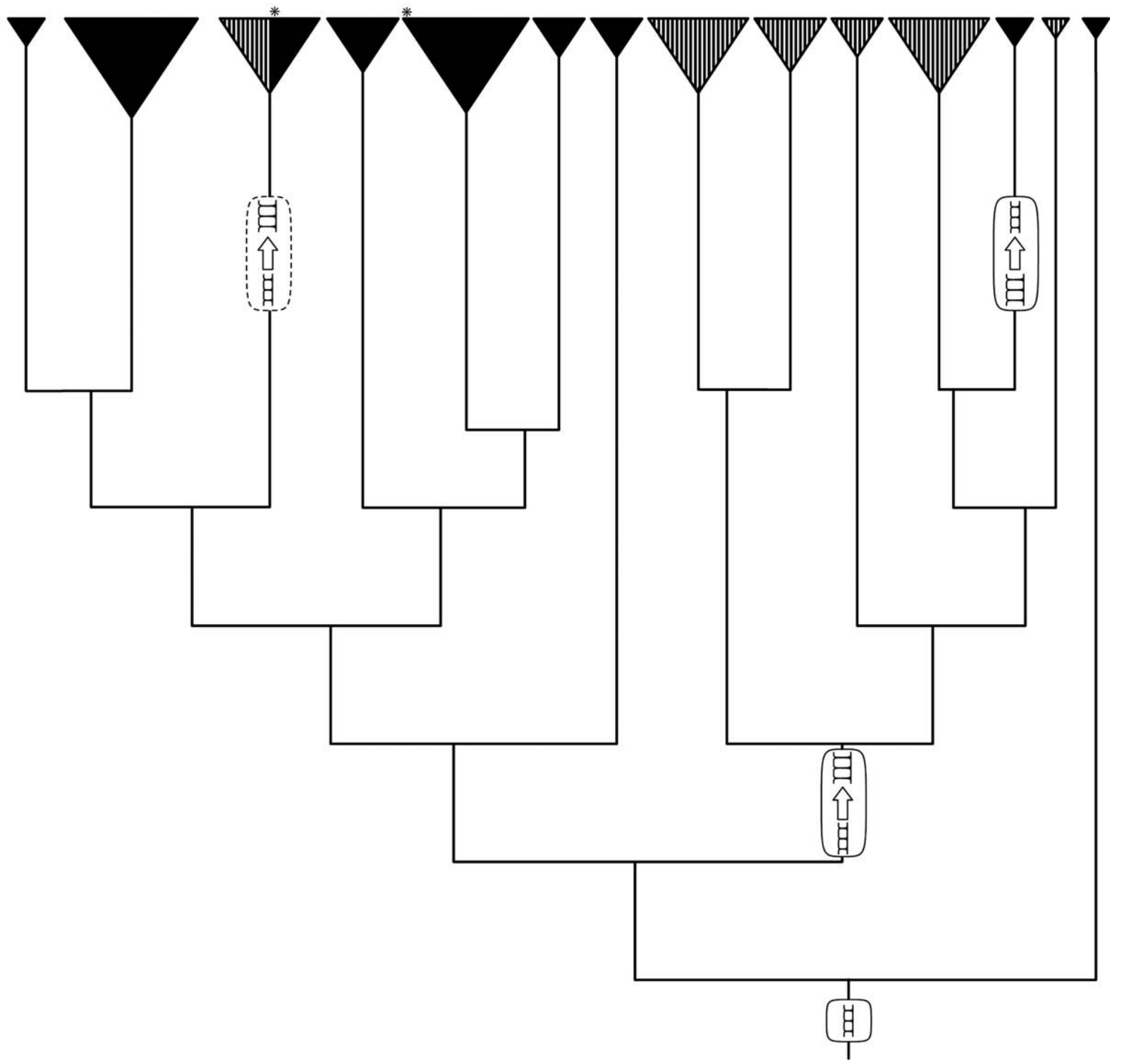

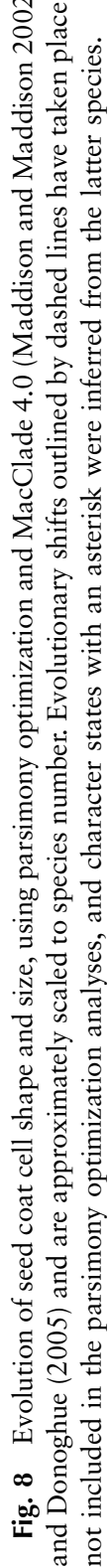


Viburnum is unknown, little can be said about the evolution toward $V$. clemensae regarding rumination.

The branch that gives rise to all species of Viburnum, with the exception of $V$. clemensae, is characterized by seeds with no rumination. This clade is marked by three shifts. A first shift from nonruminate seeds to type $2 \mathrm{~B}$ ruminate seeds took place at the base of the Tinus clade. The remaining shifts are related to type 3 rumination. Type 3 rumination has evolved in at least two separate lineages. A first shift to type 3 rumination occurred within the Solenotinus clade (see below), and a second shift took place at the base of the Pseudotinus clade.

Our broader sampling provides supplemental insights into the evolution of rumination within Viburnum. First, the investigation of $V$. davidii and $V$. tinus, combined with camera lucida drawings of seed cross sections of additional species, shows clear evidence of rumination in the remaining species of the Tinus clade. Second, our anatomical preparations of $V$. odoratissimum and $V$. sieboldii showed no sign of rumination, but we have documented a range of conditions in this group based on seed cross sections of a total of 11 species. In addition to $V$. odoratissimum and $V$. sieboldii, rumination also appears to be lacking in $V$. suspensum, V. erubescens, $V$. oliganthum, and V. chingii. However, it is well developed in $V$. brachybotrium and V. farreri, and at least weakly expressed in V. awabuki, V. foetens, and V. henryi, as well as an additional specimen of $V$. sieboldii. Our results cannot confidently support a single shift within this clade. Third, for Pseudotinus, we obtained anatomical preparations for V. lantanoides, but we can confirm that rumination is present in the remaining three species of this clade: V. cordifolium, V. furcatum, and $V$. sympodiale. Fourth, although our two representatives of Megalotinus, V. cylindricum and V. sambucinum, show no sign of rumination, the camera lucida drawings of 13 additional species of this group indicate that type 3 rumination is quite well developed in V. lepidotulum and weakly present in $V$. lutescens. This would mean that a third shift to type $3 \mathrm{ru}^{-}$ mination took place within the Megalotinus clade. It must be noted that these are the only cases where we have observed ruminate seeds in the context of the compressed and undulate endocarp shape; otherwise, rumination is confined to the circular and curved endocarp forms. Although the distribution of rumination is clear-cut for the Tinus and Pseudotinus clades, its precise distribution in Solenotinus and Megalotinus clearly requires additional sampling and an examination of the degree of variation within species.

5. Other phylogenetically useful characters. A number of other characters aid in the characterization of certain clades. Pyrene and seed shape in dorsal view, for example, is rather variable within Viburnum. Certain clades, however, are marked by a distinct pyrene and seed shape in dorsal view. Pyrenes and seeds of the Solenotinus clade, for example, seem to be characterized by a clavate outline in dorsal view (fig. 2C).

The presence of crystals in the endocarp or at the border of endocarp and mesocarp does not vary much. A few clades, however, do not possess endocarp crystals. The Lentago, Oreinodontotinus, and Pseudotinus clades illustrate this well. It should be noted, however, that only a single species of the latter two clades was included in the sampling.

In general, thick cell walls characterize the endosperm cells of Viburnum. A few clades are marked by cell walls that are only slightly thickened. The Oreinodontotinus clade, for example, has large cells with relatively thin cell walls.

From our present data (B. Jacobs, unpublished data), it is clear that several endocarp and seed characters can be used to improve and support phylogenetic relationships at generic, family, and even ordinal levels. Concerning the family Adoxaceae, seed coat anatomy, embryo size, and endocarp structure are fine examples of characters that contribute to the clarification of relationships within the family. Furthermore, the presence of small, amorphous crystals in endosperm cells is apomorphic for Viburnum within the family Adoxaceae and most likely within the order Dipsacales as a whole. Further investigation is necessary to confirm these findings.

\section{Interaction of Tissues and Transfer of Function}

The pericarp of a fruit is made up of three tissues, i.e., the exocarp, the mesocarp, and the endocarp. Within Viburnum, the exocarp is always a thin layer of small cells, whereas the mesocarp and endocarp differ considerably with respect to size and number of cell layers as well as effect on the shape and size of the mature fruit. Our results clearly show (1) a correlation between size and texture (i.e., anatomy) of the mesocarp and pyrene shape and (2) an interaction between mesocarp and endocarp.

The correlation between the size and texture of the mesocarp and pyrene shape is found throughout Viburnum. Discoid pyrenes (e.g., the Opulus, Lentago, and Lantana clades) are linked to fruits with a well-developed, succulent mesocarp composed of relatively large mesocarp cells (fig. $3 A$ ). The mesocarp is the main component of the fruit in terms of volume. Members of the Opulus clade, for example, bear bright red, juicy, sour-tasting fruits that tend to persist on the plant over winter. A slightly different situation is found in the Lentago clade. This species group is marked by fruits that are purple to blue (often with a waxy bloom), and the mesocarp is mealy and sweet at maturity. Globoid, cylindrical, and curved-discoid pyrenes (e.g., the Tinus, Solenotinus, and Oreinodontotinus clades), on the other hand, are linked to dark purple drupes with a mealy or gritty mesocarp composed of much smaller cells. Here, the pyrene constitutes the main part of the fruit, while the mesocarp is reduced to a thin layer of small cells. In general, it is our impression that globoid, cylindrical, and curved-discoid pyrenes are found in smaller fruits and that discoid pyrenes are found in larger fruits.

A detailed fruit developmental study is needed to shed light on the pathways behind these patterns. As mentioned above, these differences in morphology and anatomy most likely affect the way the fruits are dispersed as well and therefore the ecology of the species.

Maciejewska (1998) published an overview of seed and pyrene morphology of the Caprifoliaceae of Poland in which she describes the pyrenes of V. opulus and V. lantana. Maciejewska suggests that the sculpture of the pyrene surface (cf. fig. $3 G-3 I$ ) is caused by the morphology of the endocarp cells. Our results, however, conflict with this assumption, showing that the cells of the mesocarp shape the outer surface of the pyrene (i.e., endocarp), which can be seen on anatomical sections of the endocarp (cf. fig. 3A-3C). In other words, the sculpture of the pyrene surface provides information relating 


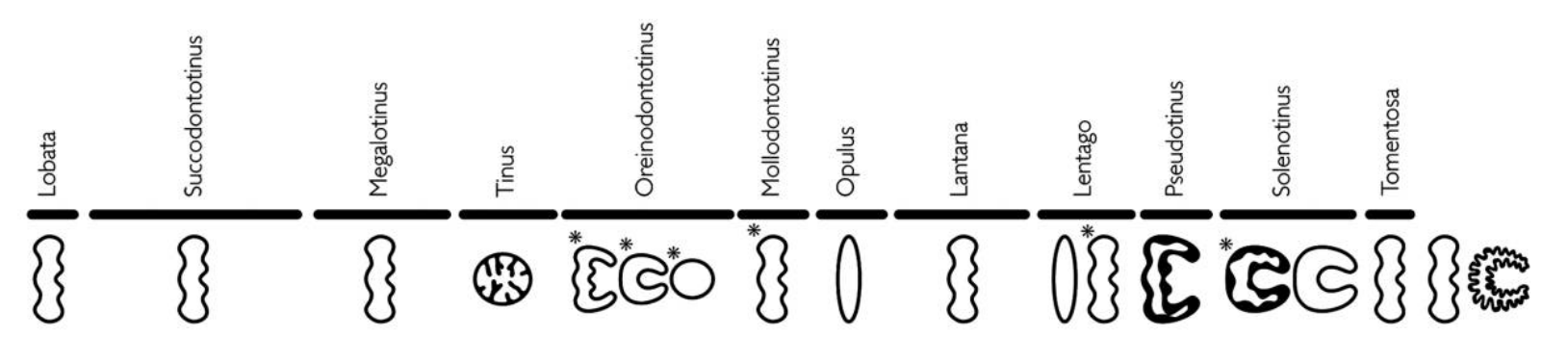

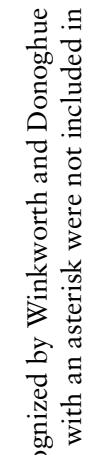

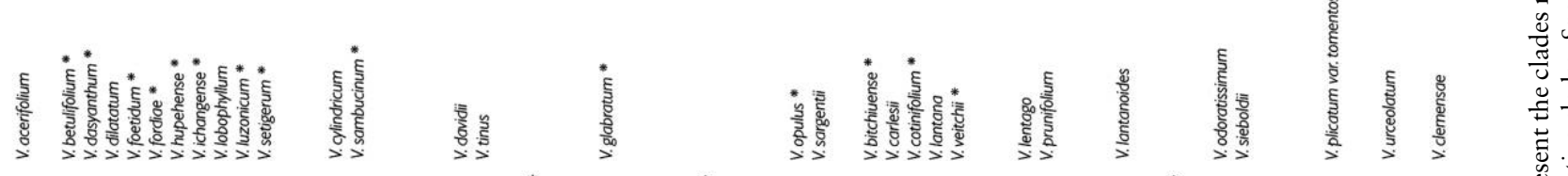

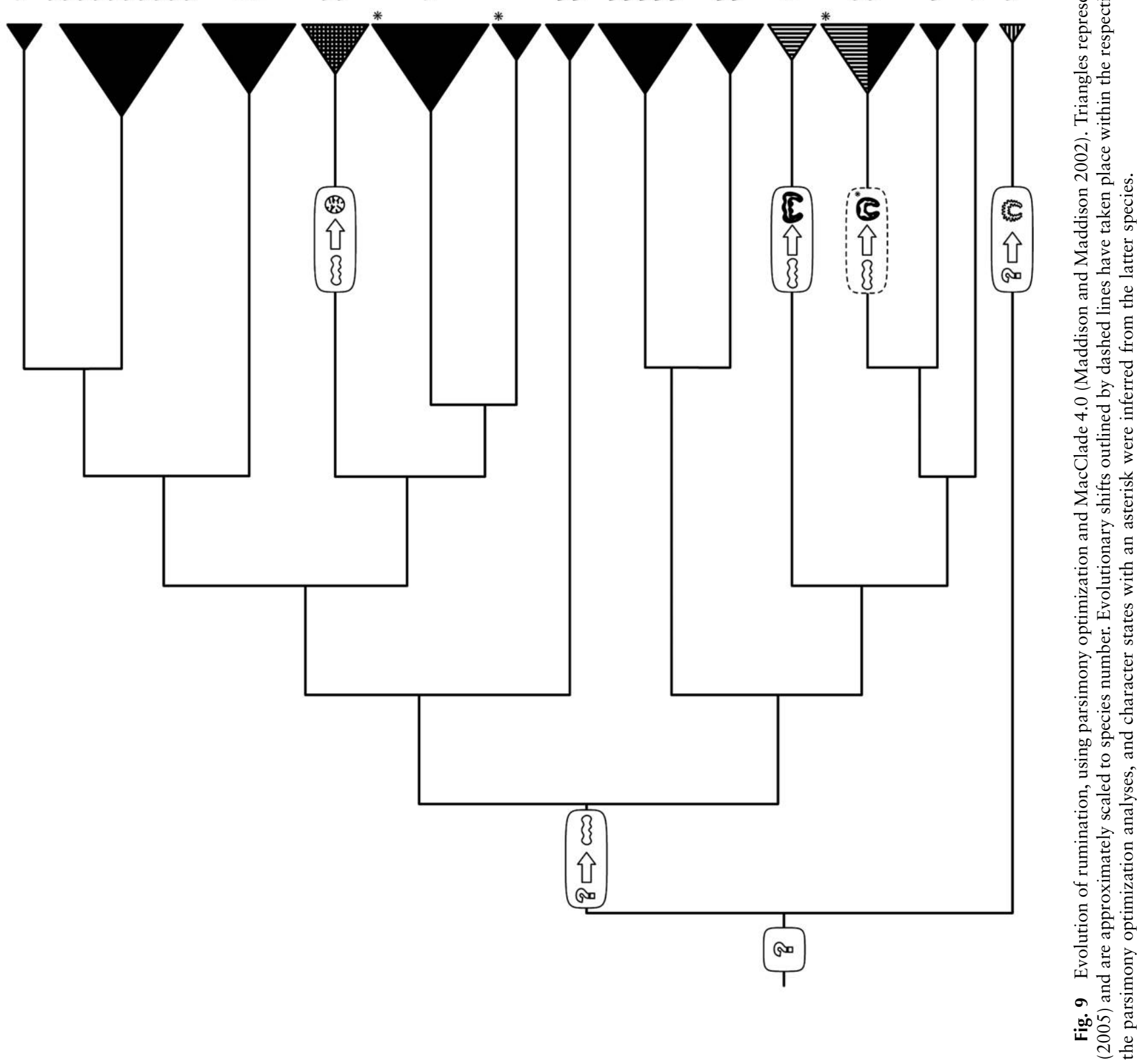


to mesocarp anatomy instead of endocarp anatomy. This might imply that the endocarp reaches its maximum strength (i.e., sclerification) only after the cells of the mesocarp are mature.

In some species (e.g., V. glabratum, V. odoratissimum, and $V$. cinnamomifolium), a similar interaction takes place between endocarp and seed coat. The main difference is that endocarp and seed coat do not adhere to each other as endocarp and mesocarp do. However, endocarp and seed coat do interact, resulting in imprints of the seed coat on the inner surface (i.e., fibers) of the endocarp (fig. $3 L$ ) or imprints of the fibers on the seed coat cells (fig. 4G). Again, this is most likely related to the development of the fruit and the relative moment at which the different tissues become mature.

The evolution from a complex, bitegmic, multiplicative seed coat (e.g., Magnoliaceae) toward a simple, unitegmic, nonmultiplicative seed coat (e.g., Adoxaceae) is a general trend that is found throughout the angiosperms (Corner 1976). In many cases, this evolutionary trend is closely linked with a transfer of function with respect to the position of the mechanical layer of the diaspore. The anatropous ovules of $\mathrm{Vi}$ burnum are unitegmic and generate a seed coat that, in general, consists of a single prominent layer at maturity that can be considered as highly derived. The thin-walled, parenchymatous cells of the seed coat are fragile and offer little or no protection. During the evolution toward Viburnum, a shift of the mechanical layer, and therefore a shift of function, has taken place. Within Viburnum and other closely related taxa, the protective function is taken over by the sclerified endocarp.

\section{Phylogenetic and Systematic Implications}

Our results provide additional support for some of the findings of Winkworth and Donoghue (2005) and bring forth some additional insights regarding the phylogenetic relationships within Viburnum. One of the most interesting outcomes of the study is the ability of the endocarp and seed characters to delimit and support the species groups delimited by Winkworth and Donoghue (2005) on the basis of molecular data. Although several species groups are marked by a certain degree of variation (e.g., Oreinodontotinus regarding pyrene shape), the majority of the species groups are characterized by distinct character states with respect to the discussed morphological and anatomical characters. Furthermore, several characters support the monophyly of higher-level clades and the split between those clades. Seed coat anatomy, for example, supports the basal split between the Imbricotinus clade and the other species groups of Viburnum (excluding $V$. clemensae). A few exceptions (e.g., in the Megalotinus clade) do not agree with this split. The maximum number of fibers provides a similar phylogenetic signal; however, homoplasy causes the signal to be less easy to interpret. The character pyrene shape is most useful and provides support for several clades, such as the clade consisting of Erythrodontotinus and Megalotinus.

Despite the fact that Megalotinus is poorly sampled, it is likely that it is paraphyletic, based on the differences between V. cylindricum and V. sambucinum. Seed coat cell shape and size, as well as endocarp structure and thickness, are key characters that support our hypothesis.

The position of $V$. clemensae as the first diverging clade is of great importance when it comes to character evolution. Hara
(1983) placed V. clemensae in section Solenotinus, together with V. odoratissimum, V. sieboldii, and a number of other species. The phylogenetic analyses of Winkworth and Donoghue (2005) conflict with this hypothesis in several ways. According to their results, $V$. clemensae is not closely related to V. odoratissimum, V. sieboldii, and the rest of the Solenotinus clade, and this causes Hara's section Solenotinus to be paraphyletic. Furthermore, as mentioned above, the analyses of Winkworth and Donoghue (2005) suggest that V. clemensae is sister to the rest of the genus. Our results support this hypothesis. Characters such as rumination suggest that V. clemensae diverged early. The only characteristics that support Hara's assignment of $V$. clemensae to section Solenotinus are the clavate pyrene shape in dorsal view and the curved, nonundulate shape in cross section. All members of the Solenotinus clade are marked by these features, although it must be noted that they are not unique to this clade. Furthermore, several species of the Solenotinus clade are marked by type 3 rumination, which is fundamentally different from the type $2 \mathrm{~A}$ rumination characterizing V. clemensae.

Hara (1983) assigned V. urceolatum to his section Viburnum on the basis of a combination of morphological characters. Molecular data (e.g., Winkworth and Donoghue 2005), however, contradict this and place V. urceolatum as sister to the clade containing Tomentosa and Solenotinus. Our results provide evidence for both hypotheses. By pyrene shape and grooving, V. urceolatum is linked to the Lantana clade (Hara's section Viburnum). However, this character state also marks the Tomentosa clade, as well as the ancestor that gave rise to Viburnum after the initial split with V. clemensae (fig. $5 \mathrm{~A}$ of Winkworth and Donoghue 2005). The maximum number of fibrous layers supports the view of Winkworth and Donoghue (2005) because V. urceolatum and the Tomentosa clade both have only a single layer of fibers (their fig. 5B). With this in mind, V. urceolatum might be linked not to the Lantana clade but instead to the Tomentosa clade. Additional data are required to address this question.

The single optimal maximum likelihood tree of the combined analysis of Winkworth and Donoghue (2005) indicates that the Lentago clade is paraphyletic. Their results imply that V. nudum is sister to the clade containing Lantana and Lentago. Our results confirm that V. nudum, together with $V$. obovatum, deviates from the rest of the Lentago clade. Additional anatomical data might strengthen this hypothesis.

\section{Future Directions}

An expanded sampling, especially of the Oreinodontotinus and Mollodontotinus clades, is needed to further clarify the evolution of endocarp and seed characters as well as to provide support for the phylogenetic relationships within Viburnum. In order to improve our understanding of character evolution, however, a better-resolved phylogeny of Viburnum is necessary. Furthermore, a broader sampling is required in order to allow the study of character evolution within particular clades (e.g., Megalotinus and Lentago) as well as at the base of Viburnum.

A fruit ontogenetic study would improve our understanding of several aspects, such as the link between different pyrene shapes and the interaction between mesocarp, endocarp, 
and seed coat. Studying fruit development is also the key to answering questions related to seed development, for example, the relationship of the smaller seed coat cells adjacent to the prominent cell layer, the development of ruminate seeds, and the ontogenetic differences between type 2 and type 3 rumination.

\section{Acknowledgments}

We thank the seed banks of the St. Andrews Botanic Garden, the National Botanic Garden of Belgium, the Institute of Ecology and Botany of the Hungarian Academy of Sciences, the Shanghai Botanical Garden, the Botanical Garden of Jena, the Botanic Garden of Smith College, the Botanic Garden of Montréal, and the Botanical Garden of Nantes for sending us dried fruits or pyrenes. Fresh material was kindly provided by the National Botanic Garden of Belgium and the Royal Botanic Garden of Edinburgh. Finally, we also thank the herbaria of the National Botanic Garden of Belgium and the Nationaal Herbarium Nederland, Leiden University Branch, for giving us access to their herbaria in order to improve the sampling with a number of key taxa. Many thanks go to Rudy Swennen, Eva De Boever, and the Katholieke Universiteit Leuven Department of Metallurgy and Materials Engineering for their advice and assistance regarding the determination of crystal composition. Finally, we kindly thank Anja Vandeperre for help and support with respect to the protocols and techniques used in the course of this study and the two reviewers for providing us with constructive comments and suggestions to improve the quality of the manuscript.

\section{Appendix}

Table A1

Classification and Collection Details for Sampled Viburnum Species

\begin{tabular}{|c|c|c|c|c|c|c|}
\hline Taxon & $\begin{array}{l}\text { Hara }(1983) \\
\text { sections }\end{array}$ & $\begin{array}{l}\text { Winkworth and } \\
\text { Donoghue (2005) } \\
\text { species group }\end{array}$ & $\begin{array}{l}\text { Accession } \\
\text { no. }\end{array}$ & Collector $^{\mathrm{a}}$ & Location & Material $^{\mathrm{b}}$ \\
\hline V. acerifolium $\mathrm{L}$. & Odontotinus & Lobata & 84 & na & $\begin{array}{l}\text { St. Andrews Botanic Garden, } \\
\text { Great Britain }\end{array}$ & $\mathrm{S}$ \\
\hline V. betulifolium Batalin & Odontotinus & Succodontotinus & 19826306 & na & National Botanic Garden of Belgium & $\mathrm{F}$ \\
\hline V. bitchiuense Makino & Viburnum & Lantana & $2005-577$ & na & $\begin{array}{l}\text { Institute of Ecology and Botany, } \\
\text { Hungarian Academy of Sciences }\end{array}$ & $\mathrm{S}$ \\
\hline V. carlesii Hemsley & Viburnum & Lantana & $2005-578$ & na & $\begin{array}{l}\text { Institute of Ecology and Botany, } \\
\text { Hungarian Academy of Sciences }\end{array}$ & $\mathrm{S}$ \\
\hline V. clemensae Kern & Solenotinus & None & L 0515238 & J. Clemens & $\begin{array}{l}\text { Nationaal Herbarium Nederland, } \\
\text { Leiden University Branch }\end{array}$ & $\mathrm{H}$ \\
\hline V. clemensae Kern & Solenotinus & None & L 0515239 & J. Clemens & $\begin{array}{c}\text { Nationaal Herbarium Nederland, } \\
\text { Leiden University Branch }\end{array}$ & $\mathrm{H}$ \\
\hline V. clemensae Kern & Solenotinus & None & L 0515247 & J. Clemens & $\begin{array}{l}\text { Nationaal Herbarium Nederland, } \\
\text { Leiden University Branch }\end{array}$ & $\mathrm{H}$ \\
\hline V. cotinifolium D. Don. & Viburnum & Lantana & $2005-579$ & na & $\begin{array}{l}\text { Institute of Ecology and Botany, } \\
\text { Hungarian Academy of Sciences }\end{array}$ & $\mathrm{S}$ \\
\hline \multicolumn{7}{|l|}{ V. cylindricum } \\
\hline Ham. ex D. Don. & Megalotinus & Lantana & 2001-313 & na & $\begin{array}{l}\text { Institute of Ecology and Botany, } \\
\text { Hungarian Academy of Sciences }\end{array}$ & S \\
\hline V. dasyanthum Rehder & Odontotinus & Succodontotinus & 19699386 & na & $\begin{array}{l}\text { Royal Botanic Garden Edinburgh, } \\
\text { Great Britain }\end{array}$ & $\mathrm{F}$ \\
\hline V. davidii Franch. & Tinus & Tinus & 85 & na & $\begin{array}{l}\text { St. Andrews Botanic Garden, } \\
\text { Great Britain }\end{array}$ & $\mathrm{S}$ \\
\hline V. dilatatum Thunb. & Odontotinus & Succodontotinus & $2005-580$ & na & $\begin{array}{l}\text { Institute of Ecology and Botany, } \\
\text { Hungarian Academy of Sciences }\end{array}$ & $\mathrm{S}$ \\
\hline V. foetidum Wall. & Odontotinus & Succodontotinus & 2001-314 & na & $\begin{array}{l}\text { Institute of Ecology and Botany, } \\
\text { Hungarian Academy of Sciences }\end{array}$ & $\mathrm{S}$ \\
\hline V. fordiae Hance & Odontotinus & Succodontotinus & 252 & na & Shanghai Botanical Garden, China & $\mathrm{S}$ \\
\hline V. glabratum H. B. \& K. & Oreinotinus & Oreinodontotinus & 3949 & $\ldots$ & National Botanic Garden of Belgium & $\mathrm{H}$ \\
\hline V. glabratum H. B. \& K. & Oreinotinus & Oreinodontotinus & 4599 & $\begin{array}{l}\text { H. Pittier and } \\
\text { Th. Durand }\end{array}$ & National Botanic Garden of Belgium & $\mathrm{H}$ \\
\hline V. hupehense Rehder & Odontotinus & Succodontotinus & $2005-581$ & na & $\begin{array}{l}\text { Institute of Ecology and Botany, } \\
\text { Hungarian Academy of Sciences }\end{array}$ & $\mathrm{S}$ \\
\hline V. ichangense Rehder & Odontotinus & Succodontotinus & 253 & na & Shanghai Botanical Garden, China & $\mathrm{S}$ \\
\hline V. lantana $\mathrm{L}$. & Viburnum & Lantana & 2119 & na & Botanical Garden of Jena, Germany & $\mathrm{S}$ \\
\hline V. lantanoides Michaux & Pseudotinus & Pseudotinus & 32 & na & $\begin{array}{l}\text { Botanic Garden of Smith College, } \\
\text { Northampton, MA }\end{array}$ & $\mathrm{S}$ \\
\hline V. lantanoides Michaux & Pseudotinus & Pseudotinus & 56336 & M. R. E. Rouleau & National Botanic Garden of Belgium & $\mathrm{H}$ \\
\hline V. lentago L. & Lentago & Lentago & 41 & na & Botanic Garden of Montréal, Canada & $\mathrm{S}$ \\
\hline V. lobophyllum Graebn. & Odontotinus & Succodontotinus & 19251065 & na & $\begin{array}{l}\text { Royal Botanic Garden Edinburgh, } \\
\text { Great Britain }\end{array}$ & $\mathrm{F}$ \\
\hline V. luzonicum Rolfe & Odontotinus & Succodontotinus & 804 & na & Botanical Garden of Nantes, France & $\mathrm{S}$ \\
\hline V. odoratissimum Ker Gawler & Solenotinus & Solenotinus & 806 & na & Botanical Garden of Nantes, France & $\mathrm{S}$ \\
\hline
\end{tabular}




\section{Table A1}

(Continued)

\begin{tabular}{|c|c|c|c|c|c|c|}
\hline Taxon & $\begin{array}{c}\text { Hara }(1983) \\
\text { sections }\end{array}$ & $\begin{array}{l}\text { Winkworth and } \\
\text { Donoghue }(2005) \\
\text { species group }\end{array}$ & $\begin{array}{l}\text { Accession } \\
\text { no. }\end{array}$ & Collector $^{\mathrm{a}}$ & Location & Material $^{\mathrm{b}}$ \\
\hline V. opulus L. & Opulus & Opulus & 19812112 & na & National Botanic Garden of Belgium & $\mathrm{F}$ \\
\hline V. opulus L. & Opulus & Opulus & $2004-222$ & na & $\begin{array}{l}\text { Institute of Ecology and Botany, } \\
\text { Hungarian Academy of Sciences }\end{array}$ & $\mathrm{S}$ \\
\hline \multicolumn{7}{|l|}{ V. plicatum var. tomentosum } \\
\hline (Thunb.) Miquel & Tomentosa & Tomentosa & 972060502 & N. Fukuoka & $\begin{array}{c}\text { Nationaal Herbarium Nederland, } \\
\text { Leiden University Branch }\end{array}$ & $\mathrm{H}$ \\
\hline V. prunifolium L. & Lentago & Lentago & 33 & na & $\begin{array}{l}\text { Botanic Garden of Smith College, } \\
\text { Northampton, MA }\end{array}$ & $\mathrm{S}$ \\
\hline V. rhytidophyllum Hemsley & Viburnum & Lantana & $2005-585$ & na & $\begin{array}{l}\text { Institute of Ecology and Botany, } \\
\text { Hungarian Academy of Sciences }\end{array}$ & $\mathrm{S}$ \\
\hline \multicolumn{7}{|l|}{ V. sambucinum Reinw. ex } \\
\hline Blume & Megalotinus & Megalotinus & 973290 & $\ldots$ & $\begin{array}{l}\text { Nationaal Herbarium Nederland, } \\
\text { Leiden University Branch }\end{array}$ & $\mathrm{H}$ \\
\hline V. sargentii Koehne & Opulus & Opulus & $2005-586$ & na & $\begin{array}{l}\text { Institute of Ecology and Botany, } \\
\text { Hungarian Academy of Sciences }\end{array}$ & $\mathrm{S}$ \\
\hline V. setigerum Hance & Odontotinus & Succodontotinus & $2005-588$ & na & $\begin{array}{l}\text { Institute of Ecology and Botany, } \\
\text { Hungarian Academy of Sciences }\end{array}$ & $\mathrm{S}$ \\
\hline V. sieboldii Miquel & Solenotinus & Solenotinus & 125391 & $\begin{array}{l}\text { N. Fukuoka } \\
\text { and K. Shimiru }\end{array}$ & $\begin{array}{l}\text { Nationaal Herbarium Nederland, } \\
\text { Leiden University Branch }\end{array}$ & $\mathrm{H}$ \\
\hline V. tinus L. & Tinus & Tinus & 1976GR00087 & na & $\begin{array}{l}\text { Nationaal Herbarium Nederland, } \\
\text { Utrecht University branch }\end{array}$ & $\mathrm{S}$ \\
\hline V. tinus L. & Tinus & Tinus & 87 & na & $\begin{array}{l}\text { St. Andrews Botanic Garden, } \\
\text { Great Britain }\end{array}$ & $\mathrm{S}$ \\
\hline V. veitchii Wright & Viburnum & Lantana & 2131 & na & Botanical Garden of Jena, Germany & $\mathrm{S}$ \\
\hline
\end{tabular}

a na $=$ not available.

${ }^{\mathrm{b}} \mathrm{F}=$ fresh material; $\mathrm{H}=$ herbarium; $\mathrm{S}=$ seed bank.

\section{Literature Cited}

APG (Angiosperm Phylogeny Group) II 2003 An update of the Angiosperm Phylogeny Group classification for the orders and families of flowering plants: APG II. Bot J Linn Soc 141:399-436.

Barthlott W 1981 Epidermal and seed surface characters of plants: systematic applicability and some evolutionary aspects. Nord J Bot $1: 345-355$.

Corner EJH 1976 The seeds of dicotyledons. Cambridge University Press, Cambridge.

Cronquist A 1981 An integrated system of classification of flowering plants. Columbia University Press, New York.

Cross GL 1938 A comparative histogenetic study of the bud scales and foliage leaves of Viburnum opulus. Am J Bot 25:246-258.

Dahlgren G 1989 An updated angiosperm classification. Bot J Linn Soc 100:197-203.

Dahlgren R 1980 A revised system of classification of the angiosperms. Bot J Linn Soc 80:91-124.

Donoghue MJ 1981 Growth patterns in woody plants with examples from the genus Viburnum. Arnoldia 41:2-23.

- 1983a The phylogenetic relationships of Viburnum. Pages 143-166 in NI Platnick, VA Funk, eds. Advances in cladistics. Vol 2. Columbia University Press, New York.

- 1983b A preliminary analysis of phylogenetic relationships in Viburnum (Caprifoliaceae s.l.). Syst Bot 8:45-58.

1985 Pollen diversity and exine evolution in Viburnum and the Caprifoliaceae sensu lato. J Arnold Arbor Harv Univ 66:421-469.

Donoghue MJ, BG Baldwin, J Li, RC Winkworth 2004 Viburnum phylogeny based on chloroplast trnK intron and nuclear ribosomal ITS DNA sequences. Syst Bot 29:188-198.

Donoghue MJ, CD Bell, J Li 2001 Phylogenetic patterns in Northern Hemisphere plant geography. Int J Plant Sci 162(suppl): S41-S52.
Donoghue MJ, CD Bell, RC Winkworth 2003 The evolution of reproductive characters in Dipsacales. Int J Plant Sci 164(suppl): S453-S464.

Eriksson T, MJ Donoghue 1997 Phylogenetic relationships of Sambucus and Adoxa (Adoxoideae, Adoxaceae) based on nuclear ribosomal ITS sequences and preliminary morphological data. Syst Bot 22:555-573.

Fukuoka N 1972 Taxonomic study of the Caprifoliaceae. Mem Fac Sci Kyoto Univ Ser Biol 6:15-58.

Hara H 1983 A revision of the Caprifoliaceae of Japan with reference to allied plants in other districts and the Adoxaceae. Academia Scientific Books, Tokyo.

Hutchinson J 1967 The genera of flowering plants. Clarendon, Oxford. 1973 The genera of flowering plants. 2nd ed. Oxford University Press, London.

Kern JH 1951 The genus Viburnum (Caprifoliaceae) in Malaysia. Reinwardtia 1:107-170.

Maciejewska I 1998 Seed and stone morphology of the Polish species of the family Caprifoliaceae. Fragm Florist Geobot 43: 189-214.

Maddison WP, DR Maddison 2002 MacClade 4: interactive analysis of phylogeny and character evolution. Sinauer, Sunderland, MA.

Martin AC 1946 The comparative internal morphology of seeds. Am Midl Nat 36:513-660.

Mayer V 1995 The epicalyx in fruits of Scabiosa and Tremastelma (Dipsacaceae): anatomy and ecological significance. Bot Jahrb Syst 117:333-357.

Mayer V, F Ehrendorfer 1999 Fruit differentiation, palynology, and systematics in the Scabiosa group of genera and Pseudoscabiosa (Dipsacaceae). Plant Syst Evol 216:135-166.

2000 Fruit differentiation, palynology, and systematics in 
Pterocephalus Adanson and Pterocephalodes, gen. nov. (Dipsacaceae). Bot J Linn Soc 132:47-78.

Mayer V, E Svoma 1998 Development and function of the elaiosome in Knautia (Dipsacaceae). Bot Acta 111:402-410.

Oersted AS 1861 Til belysning af slaegten Viburnum. Vidensk Medd Dan Nathist Foren 13:267-305.

Rehder A 1940 Manual of cultivated trees and shrubs. Macmillan, New York.

Takhtajan AL 1980 Outline of a classification of flowering plants (Magnoliophyta). Bot Rev 46:225-359.

2000 Dicotyledones Rosidae II. Pages 362-413 in A Takhtajan, ed. Anatomia seminum comparativa. Vol 6. Nauka, St. Petersburg.
Thorne RF 1976 A phylogenetic classification of the Angiospermae. Evol Biol 9:35-106.

Werker E 1997 Seed anatomy. Borntraeger, Berlin.

Wilkinson AM 1948 Floral anatomy and morphology of some species of the genus Viburnum of the Caprifoliaceae. Am J Bot 35:455465.

Winkworth RC, MJ Donoghue 2004 Viburnum phylogeny: evidence from the duplicated nuclear gene GBSSI. Mol Phylogenet Evol 33: $109-126$.

2005 Viburnum phylogeny based on combined molecular data: implications for taxonomy and biogeography. Am J Bot 92: 653-666. 